\title{
Students' School Performance in Language and Mathematics: Effects of Hope on Attributions, Emotions and Performance Expectations
}

\author{
Georgia Stephanou ${ }^{1}$ \\ ${ }^{1}$ Department of Early Childhood Education, University of Western Macedonia, Florina, Greece \\ Correspondence: Georgia Stephanou, Department of Early Childhood Education, University of Western \\ Macedonia, Florina, 53100, Greece. E-mail: gstephanou@uowm.gr \& egokesy1@otenet.gr
}

Received: March 3, 2012 Accepted: March 16, 2012 Published: June 1, 2012

doi:10.5539/ijps.v4n2p93 URL: http://dx.doi.org/10.5539/ijps.v4n2p93

\begin{abstract}
This study examined (a) students' $(n=342$, both genders, grades 5 and 6 ) attributions and emotions for their subjectively perceived school performance in language and mathematics as successful or unsuccessful, (b) the role of students' hope (pathways thinking, agency thinking) in the: perceived performance in the above school subjects as successful or unsuccessful, subsequent attributions and emotions, impact of attributions on emotions, and,in turn,interactive effect on performance expectations. The estimated as successful and unsuccessful school performance was predominately attributed to stable and unstable (external in language) factors, respectively. The students experienced intense positive and moderate negative emotions for the perceived successful and unsuccessful school performance, respectively. Hope (mainly, agency thinking) positively influenced the attributions (particularly, stability) and emotions (mainly, pathway thinking), and the impact of attributions on emotions, mainly in unsuccessful performance in mathematics. Hope, attributions and emotions had unique and complimentarily effect on performance expectations.
\end{abstract}

Keywords: attributions, emotions, hope, performance expectations

\section{Introduction}

Children's experience of academic success or failure, particularly in important domains, such as mathematics and language, is crucial for their personal identity and development (Hannover \& Kessels, 2004; Harter, 1999; Ilgen \& Davis, 2000; Mason, 2003; Paris, Morrison, \& Miller, 2006; Pintrich \& Schunk, 2002; Rutter \& Maughan, 2002; Wigfield, Brynes, \& Eccles, 2006). Therefore, it is important to understand the factors that promote or inhibit students in pursuit their educational goals.

Previous research has documented that even talented young students fail to achieve at levels that are in consistency with their academic potentials (Diener \& Dweck, 1980; Hanson, 1994; Stephanou, 2004a). Also, the psychological consequences of academic success or failure are influenced by the beliefs and goals that students have (Boekaerts, 2002; Dweck, 1999; Eccles \& Wigfield, 1995; Linnenbrink \& Pintrich, 2000, 2002; Marsh \& Craven, 1997; Mason, 2003; Stephanou, 2007a, 20011b).

Recent research on student motivation focuses on socio-cognitive and emotional constructs and their role in academic achievement (Anderman \& Wolters, 2006; Boekaerts, Pintrich, \& Zeidner, 2000; Schutz \& DeCuir, 2002; Schutz, Hong, Cross \& Osbon, 2006; Stephanou, 2006, 2008; Stephanou \& Kyridis, in press; Stephanou \& Tatsis, 2008; Wosnitza, Karabenick, Efklides \&Nenniger, 2009).

Weiner's $(1992,2005)$ attribution model of motivation, on which this study is partly based, incorporates a variety of these constructs, and it has proved helpful in understanding children's academic achievement (see Anderman \& Wolters, 2006; Schunk \& Zimmerman, 2006). Specifically, Weiner's (2005) attribution model perceives affects and expectations as immediate predecessors of academic achievement. The findings from previous investigations have documented that attributions for past performance influence future performance, since they have psychological consequences relative to expectancy and affects (Pintrich \& Schunk, 2002; Stephanou, 2004b, 2005; Weiner, 1992). Whether students perceive their academic performance as successful or unsuccessful, and which explanations or interpretations they make about their performance influence their emotions, motivation and behaviour. For example, if a student attributes his / her successful course performance to internal, controllable and stable factors (e.g., long- term effort), he / she may experience pride and expect future success. In contrast, by attributing failure to internal, uncontrollable and stable factors (e.g., low ability), a student may 
experience incompetence and shame, have low expectations of success, and decreases the probability of successful performance. Furthermore, a student, who experiences repeated shame and hopelessness in a school course, will be likely to avoid being involved in that course in the future (see Eccles \& Wigfield, 2000; Stephanou, 2004a).

Emotions are inherently and intensely experienced in the context of education, they play important role in future behaviour, and so they are needed to be included in any comprehensive discussion of academic achievement (Meyer \& Turner, 2002; Pekrun, 2009; Pekrun \& Schutz, 2007; Weiner, 2002, 2005). For example, emotions have significant and positive effects on cognitive information processing, motivation, quality of thinking, learning strategies, self-regulation, metacognition and achievement (Boakaerts et al., 2000; Efklides \& Volet, 2005; Fiedler, 2002; Gasper, 2004; Goetz, Zirngibl, Pekrun \& Hall, 2003; Pekrun, Goetz, Daniels, Stupnisky, \& Perry, 2010; Stephanou, Kariotoglou \& Ntinas, 2011).

Similarly, research efforts have targeted the significant role of success expectations in academic achievement. High expectations for success are related to task engagement, persistence in carrying out tasks, effective use of cognitive and meta-cognitive strategies, and successful performance (see Eccles \& Wigfield, 2000; 2002; Efklides, 2001; Stephanou, 2006, 2008; Wigfield \& Eccles, 2002; Zimmerman, 2000).

However, as Snyder, Shorey, Cheavens, Pulvers, Adams III, and Wiklund (2002) suggest, although the above constructs have contributed to better understanding of academic performance, each explains a part of student motivation. In Snyder's (2000) hope theory, hope, incorporating the motivation to move towards goals and the ways to achieve these goals, is a dynamic cognitive motivational system. According to this sense, emotions follow cognitions in the process of goal pursuits. Also, hope is positively related to competence beliefs and outcome expectations (Snyder, Irving \& Anderson, 1991). Consequently, hope enables students to deal with problem with a focus on success, and, thus, enhances the chances of attaining their goals (Conti, 2000). For example, previous studies (e.g., McDermott \& Snyder 2000; Stephanou, 2010) have indicated that children's high hope moderately predicts high school achievement tests for grade school children (McDermott \& Snyder, 2000).

Hope also influences how children interpret and feel for their achievement (Roberts, Brown, Johnson \& Reinke, 2005). More accurately, although in hope theory the focus is on reaching desired future goal-related outcomes, hope is related to attributions for past behaviour, since both theories elaborate pursuit goals and important outcomes (see Seligman, 1991; Snyder, Rand \& Sigmon, 2005; Weiner, 2005). Hope is associated with emotions in a given achievement situation, since goal-pursuit cognitions, such as avoiding or alleviating harm or maximizing benefits in it, cause emotions (Smith \& Ellsworth, 1987; Snyder et al., 2005). Besides, emotions arise 'in response to the meaning structures of given situations' (Frijda, 1988, p. 349), and the appraisal of a certain learning situation is influenced by self-beliefs (Frijda, 2009; Weiner, 2001).

Accordantly, Snyder's $(1994,2005)$ hope theory, which is involved in this study, incorporating way power and willing power, offers an important construct in understanding how children deal with their academic- related situations (Roberts et al., 2005; Smith \& Kirby, 2000; Snyder, Cheavens \& Sympson, 1997). Besides, in agreement with Johnson and Roberts (1999), "looking at strengths rather than deficits, opportunities rather than risks, assets rather than liabilities is slowly becoming an increasing presence in the psychotherapy, education, and parenting literature" (p.50).

Researches (e.g., Snyder, Hoza, Pelham, Rapoff, Ware, Danovsky, Highberger, Rubinstein \& Stahl, 1997; Snyder, McDermott, Cook \& Rapoff, 1997; Stephanou, 2011a) have shown that the majority of children are able to use hopeful, goal-directing thought. In middle childhood and preadolescence, in particular, there is a growth in logical rather than intuitive thinking skills, which contributes to increasing hopeful planning and pursuing pathways towards value-goals and doing so within a social context of mindful of the wishes of the significant others, such peers and teachers (Carr, 2005; Snyder, 2000). Also, children tend to perceive their future positively, and have high hope (Snyder, Hoza et al., 1997; Snyder, McDermott et al., 1997; Stephanou, 2011a; Stephanou \& Balkamou, in press).

However, few investigations have studied how children's hope interacts with attributions and emotions in school achievement, and how they interactively affect performance expectations following a certain performance. Previous literature about the relationship between emotions and cognitive factors in academic achievement suggests that it is relatively domain specific and varies from one academic domain to the other (Ainley, Buckley \& Cha, 2009; Dermitzaki \& Efklides, 2000; Efklides, 2001; Goetz, Frenzel, Pekrun, Hall \& Lüdtke, 2007; Schunk\& Zimmerman, 2006; Stephanou, 2006, 2011b; Wolters \& Pintrich, 1998). Furthermore, as some researchers (e.g., Anderman, 2004; Wigfield, Guthrie, Tonks \& Perencevich, 2004) propose, students' motivation 
is better understood by contextualizing beliefs within a given domain rather than just by comparing between domains. The present study focused on mathematics and language in grades five and six, so that a more diverse picture of students' motivation is attained.

\subsection{Attributions and Emotions for Academic Achievement}

Students appraise an academic outcome by evaluating and by attributing causes (Smith \& Lazarus, 1990; Trope \& Gaunt, 2005). The appraisals reflect what the stimulus (e.g., school performance) means to the student and whether it is successful or unsuccessful (Weiner, 2002, 2005). Causal thinking, in particular, is most likely to be engaged in conditions of unexpected, negative or important outcomes (Peterson 1990; Stephanou, 2001b, 2003; Weiner, 1992, 1995).

Although, an event outcome could be attributed to infinite number of attributions, ability (aptitude or acquired skill), effort (short and long- term), task difficulty (or ease) and luck are the most prominent causes in describing academic success or failure (Graham, 1998; Weiner, 1992, 2005). However, among them, ability and effort are the most dominant ones (Schunk \& Zimmerman, 2006; Stephanou, 2005; Weiner, 2001, 2005). Attributions are categorized into dimensions of locus of causality (internal /external to the person), stability (stable / unstable over time) and controllability (personal and external controllable / uncontrollable), which have psychological and behavioral consequences (see Anderman \& Wolters, 2006; McAuley, Duncan \& Russell, 1992; Schunk\& Zimmerman, 2006; Weiner, 2001, 2005, 2006). McAuley et al. (1992) distinguish controllability into personal controllability and external controllability.

The successful / unsuccessful academic performance differentiates the attributional pattern (Fiske \& Taylor, 1991; Mullen \& Riordan, 1988; Trope \& Gaunt, 2005). Specifically, individuals tend to attribute the successful performance to themselves (internal, stable, personal controllable, and external uncontrollable causes), and the unsuccessful performance to others and situational- related factors (Peterson, Maier \& Seligman, 1993; Stephanou, 2005; Weiner, 1995, 2001, 2005, 2006).

Appraisal theory (e.g., Ellsworth \& Scherer, 2003; Frijda, 1988, 2005) of emotions has proved important in examining emotions in academic settings. The attributional appraisal perspective to emotions, especially, focuses on how specific emotions such as sadness and anger are elicited, and on the motivational functions they serve in a certain achievement condition (Weiner, 2002, 2006).

The intuitive appraisal of academic performance, which refers to students' perceptions of how good their performance was, and the attributional appraisal of performance, which concerns the perceived causes for performance, are important sources of students' emotions (Weiner, 2002). More precisely, according to Weiner's (2005) attribution theory, there are "outcome- dependent" (e.g., happiness, pleasure, sadness) emotions, that are the initial and strongest response to the valence of the performance, and the "attribution- dependent" (e.g., encouragement, anger) emotions, that are influenced by the causal explanation for the performance.

Although all attributional dimensions are related to emotions for performance, their prevalence differs across the various emotions. Specifically, locus of causality, stability and controllability mainly influences the self-esteem (pride)- expectancy (confidence)- and social (shame, anger, gratitude)- related emotions, respectively (Berndsen \& Manstead, 2007; Pintrich \& Schunk, 2002; Stephanou \& Tastis, 2008; Weiner, 1995, 2001, 2005, 2006). For example, internal attributions for successful school performance produce the feelings of confidence and pride, whereas external attributions leads to positive behaviors such as help seeking, or negative responses, such as helplessness, avoidance and lack of persistence. In contrast, attributing unsuccessful school performance to internal factors predicts incompetence, shame, guilt and resignation, whereas attributing unsuccessful performance to others causes anger, aggression and vindictiveness.

Attributing successful school performance to stable factors enhances performance expectations, and facilitates task engagement, while attributing an unsuccessful performance to unstable is likely to improve performance and minimizes the feeling of hopelessness. In contrast, attributing failure to stable factors minimizes positive expectations, produces the feeling of hopelessness and can lead to learned helplessness, a sense that none effort can lead to good performance (see Peterson \& Steen, 2005; Seligman, 2002; Weiner, 2001, 2005, 2006).

Guilt and anger are elicited by controllable causes, but guilt emerges from internal, whereas anger is elicited by external factors (Stephanou, 2004b, 2007a, 2007b; Weiner, 1992, 1995). Furthermore, anger combines distress over an undesired event with perceiving the other as responsible for it (Ortony, Clore \& Collins, 1988). Also, stable causes maximize feelings of pity, given uncontrollable causes, and feelings of anger, given controllable causes (Graham \& Hoehn, 1995).

Overall, the beliefs that a student has about the causes of his / her school performance have effects on his / her 
emotions and expectations for the future performance. Then, emotions and expectations influence the student's actual future performance.

\subsection{Association of Hope with Attributions, Emotions and Performance Expectations in Academic Achievement}

According to Snyder's (2000) hope theory, hope is a cognitive set including an individual's beliefs in his / her capacity to create effective routes to achieve goals (way power or pathways thinking) and beliefs in his / her ability to initiate and sustain movement towards those goals (willing power or agency). It is "a positive motivational state that is based on an interactively derived sense of successful agency (goal-directed energy) and pathways (planning to meet goals)" (Snyder, Harris, Anderson, Holleran, Irving, Sigmon, Yoshinobu, Gibb, Langelle \& Harney, 1991, p. 287). Agency thinking is the motivational component in hope theory, shares similarities with self-efficacy (Bandura, 1997; Snyder et al., 2005), and it is particularly crucial when individuals encounter impediments (Snyder, 1994). In such situations, agency thoughts enable the individual to direct the motivation to the best pathway among the alternative pathways (Snyder et al., 2005). Similarly, the production of several pathways is important in the case of impediments, and high-hope people are effective at initiating alternatives routes.

Within this perceptive, hope is a critical construct to understand how children deal with and work towards goals, such as succeeding at school, in an adaptive and effective manner (see Roberts et al., 2005). Measures of children's hope are positively related with self reported competence and feeling about themselves, and it is predictor of self-esteem (Snyder, McDermott, et al., 1997; Snyder, Feldman, Taylor, Schroeder \& Adams, 2000). Also, the Lewis and Kliewer's (1996) study, focusing on pediatric population, showed that hope was negatively associated with anxiety, while this association was moderated by coping strategies. A research by Barnum, Snyder, Rapof, Mani, and Thompson (1998) revealed that high-hope had protective function in children to allow them to be effective in their lives in spite of the obstacles. Also, previous researches revealed that hope, state or/ and trait, is positively associated with academic achievement. For example, Snyder, Hoza et al. (1997) found that hope is positively related to achievement test as it is reflected in grade school. Similarly, higher hope was related to higher overall grade point averages for junior high students (Lopez, Bouwkamp, Edwards \& Teramoto Pediotti, 2000) high school students (Snyder et al., 1991) and semester grade for college students (Chang, 1998; Curry, Maniar, Sondag \& Sandstedt, 1999). Peterson, Gerhardt and Rode (2006) found the positive effect of trait hope on performance in an anagram task through the state hope.

Generally, individuals with high dispositional hope enjoy life, and use positive reappraisal for a variety of stressor situation, and they not use avoidance and denial behaviour (Gilham, 2000; Snyder, 2000; Snyder, Cheavens \& Michael, 1999; Stephanou, 2011a; Stephanou \& Balkamou, in press). Hopeful people, like optimistic people, expect positive outcomes even when they face difficulties, in which they insist in pursuit their goals and regulate themselves, using effective coping strategies, so they enhance the chances to achieve their goals (Carver \& Scheier, 2005; Peterson, 2000; Scheier, Carver \& Bridges, 2000; Seligman, 1991). Hopeful people, additionally, focus not only on future goals but also on goals they believe they can achieve (see Nolen-Hoeksema \& Davis, 2005; Snyder, 2000). That means that hopeful individuals are looking for something positive in a variety of conditions. Also, some researches have suggested that optimism is predominately related to agency hope and that hope pathways has unique contribution and beyond what was affected by optimism (see Snyder et al., 2002).

Accordantly, a high hope child may use optimistic attribution pattern in explaining successful and unsuccessful school performance. Probably, a high- hope child, as an optimistic child does, attributes failure to external, unstable and specific factors instead of internal, stable and global factors (see Scheier \& Carven, 1985; Snyder et al., 2005; Seligman, 2002).

In Snyder's hope theory, emphasizing the thinking processes, 'goal-pursuit cognitions cause emotions' (Snyder et al. 2005, p. 258). Specifically, positive emotions result from perception of successful goal pursuit which reflects unimpeded movement toward the goal or effective overcoming the obstacles. In contrast, negative emotions are formulated by the perception of unsuccessful goal pursuit which may result from insufficient agency thinking and / or pathway thinking or the ineffective ability to overcome the problem. These points were supported by respective researches (e.g., Snyder, Sympson, Ybasco, Borders, Babyak \& Higgins, 1996; Stephanou, 2010), and are in agreement with findings for reported lessened well-being stern from perceived difficulties in pursuit of important goals (Diener, 1984; Ruehlman \& Wolchik, 1988).

Summarizing, hope has positive effects on thoughts, emotions, expectations and performance in academic achievement situations. 


\subsection{Subjective Perception of Success and Failure}

Usually in academic achievement, the criteria of success and failure have objectively defined, that is, what grade one gets in a specific school subject. However, performance is also perceived as successful or not, regardless of the exact grade gained. It has been long recognized that successful and unsuccessful performance outcome are better seen as psychological states, based upon students' own interpretation of performance (Dweck, 1999). For example, students' performance expectations, goals, values, and self-perceptions of ability in a specific school subject influence the perception of how successful performance is (Pintrich, 2003; Pintrich \& Schunk, 2002). Perceived performance, as compared to the objective one, has been found to be also related to students' achievement motivation and actual achievement (Weinstein, 1998; Zimmerman, 1995). For this reasons, in the present study, students defined what they consider successful performance for themselves.

\subsection{Aim and Hypotheses of the Study}

This study aimed to examine (a) students' attributions and emotions for their subjectively perceived successful and unsuccessful school performance in mathematics and language, (b) the role of students' hope (pathways thinking, agency thinking) in the perception of their school performance as successful or unsuccessful in the above school subjects, in the generation of the subsequent attributions and emotions, and in the impact of attributions on emotions, and (c) the role of students' hope (pathways thinking, agency thinking) in performance expectations, and in the interactive impact of attributions and emotions on performance expectations.

The hypotheses of the study were the following:

The perceived as successful and unsuccessful performance in each school subject will be attributed to self- and other- related factors, respectively (Hypothesis 1a). Locus of causality as compared to the rest of the attributional dimensions will be the most powerful factor in discriminating the two groups of students in mathematics and in language (Hypothesis 1b). The students will experience various emotions for the perceived successful and, particularly, unsuccessful school performance in both school subjects (Hypothesis 2a). The students, who will perceive their school performance as successful, will experience positive emotions, whereas the students, who will perceive their school performance as unsuccessful, will experience negative emotions, mainly outcome-dependent emotions (Hypothesis 2b). The perceived successful performance group, compared to perceived unsuccessful performance group, will have higher hope (mainly, agency thinking) in each school subject (Hypothesis 3a). Hope, mostly agency thinking, will have positive effects on the generation of the perception of school performance as successful and, mainly, unsuccessful (Hypothesis 3b). Hope will have positive effects on attributions, particularly stability (Hypothesis $4 \mathrm{a}$ ), on emotions, mainly expectancy- related (Hypothesis 4b), and on the impact of attributions on emotions (Hypothesis 4c) in the successful, and, particularly, the unsuccessful performance group in both school subjects. Hope will positively influence performance expectations (Hypothesis 5a), the interactive effect of attributions and emotions on performance expectations (Hypothesis 5 b), mainly in unsuccessful performance groups. There will be school subject differences but no specific hypothesis is suggested (Hypothesis 6).

\section{Method}

\subsection{Participants}

A total of 342 students, both genders, of Grades 5 and 6 participated in the study. Their age ranged from 10 to 12 years $(\mathrm{M}=11.30$ years, $\mathrm{SD}=0.55$ years $)$. They came from schools of various towns of Greece, representing various parental socioeconomic levels. According to the findings with respect to the perceived school performance as successful or unsuccessful (see measurements below), 191 and 151 students perceived their school performance in language as successful and unsuccessful, respectively. Similarly, 179 and 163 participants estimated their school performance in mathematics as successful and unsuccessful, respectively.

\subsection{Measures}

A questionnaire with separate versions for mathematics and language was constructed. The wording of the questions for the two school subjects was the same except for the subject name.

Performance expectations. The questionnaire was based on previous research (see Eccles \& Wigfield, 2002; Nagy, Trautwein, Baumert, Koller \& Garrett, 2006; Pintrich \& Schunk, 2002; Stephanou, 2008; Wigfield \& Eccles, 2002). It consisted of four questions (e.g., "How well do you think you will do on Language this school year?", "How good will your performance be in Mathematics this school year?"). Responses ranged from $1=$ very poorly to $10=$ excellent. The 10 -point scale was used to match the school marks scale. Cronbach's alphas were .83 and .85 for mathematics and language, respectively. 
Objective and subjective school performance. Teachers rated students' school performance (from 1 to 10) in both school subjects. These rates represented objective school performance. Besides school marks, students' perceptions of their school performance as successful or unsuccessful was also estimated. Students were asked to indicate how successful they thought their school performance was. Specifically, the participants indicated the lowest mark (from 1 to 10) over which their performance in each school subject would be considered successful. Students whose school mark was lower than the indicated as successful formed the group of unsuccessful performance, whereas those whose school mark was equal or higher than the indicated one formed the successful performance group.

Attributions for performance. Attributions for the perceived successful/ unsuccessful school performance in both school subjects were assessed by the slightly modified Causal Dimension Scale II (CDSII, McAuley et al., 1992; see Stephanou, 2004b, 2005). The students, first, indicated the most important cause, which, according to their opinion, influenced their performance and, then, classified that cause along the attributional dimensions of locus of causality (internal / external causes to him/ herself), stability (stable / unstable causes over time), personal controllability (controllable / uncontrollable factors by their own) and external controllability (controllable / uncontrollable by others). Each of the causal dimensions consists of three items, ranging from $1=$ negative pole (e.g., not at all stable) to $7=$ positive pole (e.g., totally stable). In mathematics, Cronbach's alphas were: .76 for locus of causality, .80 for stability, .85 for personal controllability, and .73 for external controllability. In language, Cronbach's alphas were $.80, .83, .80$ and .76 for locus of causality, stability, personal controllability and external controllability, respectively.

Emotions for performance. Children's emotions for their school performance were assessed by mentioning the extent to which they experienced ten emotions: happiness, pleasure, pride, encouragement, not angry - angry, cheerfulness, confidence, calmness, not anxiety- anxiety and enthusiasm. The emotions had the form of adjectives with two opposite poles, the positive pole, having the high score of 5, and the negative pole, having the low score of 1 (e.g., happy 54321 unhappy). The consistency of the scale was based on previous researches (see Stephanou, 2011b; Stephanou, \& Tatsis, 2008; Weiner, 1992, 2002, 2005, 2006). Cronbach's alphas were 84 and .83 for mathematics and language, respectively.

Hope. Children's dispositional hope was examined through the Children's Hope Scale for ages 8 to 16 (Snyder, Hoza, et al., 1997) which comprises three agency thinking (e.g., "I think I am doing pretty well") and three pathways thinking (e.g., "I can think of many ways to get the things in life that are most important to me") items. Responses ranged from $1=$ None of the time to $6=$ All of the time. This scale is a valid and reliable research instrument in examining dispositional hope in Greek elementary school population (see Stephanou, 2011a; Stephanou \& Balkamou, in press). In this study Cronbach's alphas were .90 and .88 for agency thinking and pathways thinking, respectively.

The participants' Personal information scale consisted of a set of questions relevant to personal factors, such as age and gender.

\subsection{Research Design and Procedure}

All the participants completed the questionnaire for each of the two subjects in the middle of the school year. The children individually completed the scales in front of the researcher in quiet classrooms in their schools. The students initially completed the hope scale, while, after one week, they responded to the rest of the scales. In order to ensure that any relationship among the examined variables was not due to procedure used, the participants completed, first, the performance expectation scale, then, the emotions scale and, finally, the attributions scale.

To match the questionnaires that were responded by the same student, students were asked to choose a code name and use it on the response sheets. To match the students with the given marks by their teachers, first, the participants and their classmates were given the school-reported grades in both school subjects, and, then, the participating children were asked to spot and rewrite their grades on a separate sheet, and to use their code name on it. Students were assured of anonymity and confidentiality

\section{Results}

\subsection{Attributions and Emotions for School Performance}

The results from the repeated measures MANOVAs (using the Wilks's lambda estimate) with the four attributional dimensions as within-subjects factor and perceived school performance (successful/ unsuccessful) as between-subjects factor revealed significant main effect of school performance, in mathematics, $\mathrm{F}(1,340)=$ 44.72, $\mathrm{p}<.01, \eta^{2}=.68$, and in language: $\mathrm{F}(1,340)=78.90, \mathrm{p}<.01, \eta^{2}=.78$. There was also significant main 
effect of attributional dimensions in mathematics, $F(3,338)=407.00, p<.01, \eta^{2}=.78$, and in language, $F(1,338)$ $=490.50 . \mathrm{p}<.01, \eta^{2}=.81$. Finally, there was significant multivariate effect in mathematics, $F(3,338)=14.00, \mathrm{p}$ $<.01, \eta^{2}=.11$, and in language, $\mathrm{F}(3,338)=39.80, \mathrm{p}<.01, \eta^{2}=.62$.

The findings from subsequent repeated measures ANOVAs, examining differences between attributions within each group of school performance (perceived successful / unsuccessful) in each school subject, post hoc pairwise comparisons and examination of the mean scores (Table 1), showed that the children mainly attributed their perceived successful school performance to stable and internal factors in both school subjects. In contrast, they predominately attributed their perceived unsuccessful performance in mathematics and language to unstable factors and both external and unstable factors, respectively.

To further specify the source of these differences, ANOVAs with the perceived school performance (successful / unsuccessful) as between-subjects factor were conducted in mathematics and language separately. These analyses revealed that the students, who estimated their school performance as successful, as compared to the students, who estimated their school performance as unsuccessful, made more internal, stable, personal controllable and external uncontrollable (not difference in mathematics) attributions. The results from Discriminant analyses (Table 1), with stepwise method, confirmed the univariate effects and, in addition, showed that stability, discriminating power $=.91$.

Table 1. Descriptive statistics and findings from discriminant analysis for students' attributions for their perceived school performance in mathematics and language as successful or unsuccessful

\begin{tabular}{|c|c|c|c|c|c|c|c|}
\hline \multirow[b]{2}{*}{ Attributional dimensions } & \multicolumn{2}{|c|}{$\begin{array}{l}\text { Successful } \\
\text { performance }\end{array}$} & \multicolumn{2}{|c|}{$\begin{array}{l}\text { Unsuccessful } \\
\text { performance }\end{array}$} & \multirow{2}{*}{$\begin{array}{l}\text { Wilks' } \\
\text { Lambda }\end{array}$} & \multirow{2}{*}{$\begin{array}{l}\text { Discriminating } \\
\text { power }\end{array}$} & \multirow[b]{2}{*}{$\mathrm{F}$} \\
\hline & Mean & SD & Mean & SD & & & \\
\hline \multicolumn{8}{|c|}{ Mathematics } \\
\hline Locus of causality & 6.15 & .83 & 5.50 & .87 & .87 & $.78^{*}$ & 49.91 \\
\hline Personal controllability & 6.11 & .92 & 5.46 & .75 & .87 & .87 & 50.94 \\
\hline Stability & 6.18 & 1.23 & 4.05 & 1.04 & .84 & .91 & 62.00 \\
\hline External controllability & 2.76 & 1.34 & 3.00 & 1.40 & .99 & $.04 *$ & 2.43 \\
\hline \multicolumn{8}{|c|}{ Language } \\
\hline Locus of causality & 6.40 & .61 & 3.95 & .85 & .69 & .84 & 152.21 \\
\hline Personal controllability & 6.24 & .85 & 5.39 & .75 & .78 & .66 & 94.90 \\
\hline Stability & 6.42 & 1.02 & 4.10 & 1.02 & .70 & .81 & 141.10 \\
\hline External controllability & 2.55 & 1.18 & 3.15 & 1.47 & .95 & $-.27 *$ & 16.60 \\
\hline
\end{tabular}

Note. $\mathrm{F}(1,340)>2.43, \mathrm{p}<.01 ; \mathrm{F}(1,340)=2.43, \mathrm{p}>.05 ; *$ : Attributional dimensions did not further differentiate the two groups of students.

It was the most powerful dimension in discriminating the successful performance group from the unsuccessful performance group in mathematics, and that locus of causality, discriminating power $=.84$, was the most powerful attributional dimension in separating the one from the other group of students in language, Also, external controllability had no significant contribution in separating the two groups of students in language and in mathematics. Similarly, locus of causality was not a significant discriminator of the two performance groups in mathematics.

Hypotheses $1 \mathrm{a}$ and $1 \mathrm{~b}$ were partly confirmed by the above results.

The repeated measures ANOVAs, examining differences between the emotions within each performance group (perceived successful / unsuccessful) and school subject, showed that the students experienced various emotions, and a variety of intensity of emotions, in mathematics: successful performance group, $F(9,170)=49.00, p<.01$, $\eta^{2}=.72$, and unsuccessful performance group, $\mathrm{F}(1,154)=32.85, \mathrm{p}<.01, \eta^{2}=.68$; and in Language: successful performance group, $\mathrm{F}(9,182)=37.16, \mathrm{p}<.01, \eta^{2}=.64$, and unsuccessful performance group, $\mathrm{F}(9,142)=$ $22.80, \mathrm{p}<.01, \eta^{2}=.59$. Inspection of the scores (Table 2 ) and the post hoc pairwise comparisons indicated that the students experienced intense positive emotions for the perceived successful school performance, mainly not 
angry, confidence, enthusiasm, happiness and encouragement. In contrast, they felt moderate negative emotions for the perceived unsuccessful school performance, particularly angry, sadness, not calmness, shame (only in mathematics) and discouragement (only in language).

Discriminant analysis, with stepwise method, was conducted to determine the set of emotions that best discriminated the two groups of children in each school subject. These analyses (Table 2) confirmed the univariate findings, and, in addition, revealed that (a) in both school subjects, the students, who estimated their school performance as successful, compared to students, who estimated their school performance as unsuccessful, felt better, expect for pleasure, anxiety-not anxiety and enthusiasm, (b) the emotion of not angry - angry, discriminating power $=.72$, followed by the emotion of confidence, discriminating power $=.41$, was the most powerful factor in discriminating the group of students with the successful school performance from the group of students with the unsuccessful school performance in mathematics, (c) the emotion of not angry - angry, discriminating power $=.68$, followed by the emotion of encouragement, discriminating power $=.60$, was the most powerful discriminator in separating the successful from the unsuccessful performance group in language and (d) the emotions of cheerfulness and calmness in language, and the emotions of cheerfulness, happiness and encouragement were found not to further differentiate the one group from the other group of students.

The above findings partly confirmed Hypotheses $2 \mathrm{a}$ and $2 \mathrm{~b}$.

Table 2. Descriptive statistics and findings from discriminant analyses for students' emotions for their perceived school performance in mathematics and language as successful or unsuccessful

\begin{tabular}{|c|c|c|c|c|c|c|c|}
\hline \multirow[b]{2}{*}{ Emotions } & \multicolumn{2}{|c|}{$\begin{array}{l}\text { Successful } \\
\text { performance }\end{array}$} & \multicolumn{2}{|c|}{$\begin{array}{l}\text { Unsuccessful } \\
\text { performance }\end{array}$} & \multirow{2}{*}{$\begin{array}{l}\text { Wilks' } \\
\text { Lambda }\end{array}$} & \multirow{2}{*}{$\begin{array}{c}\text { Discriminating } \\
\text { power }\end{array}$} & \multirow[b]{2}{*}{$\mathrm{F}$} \\
\hline & Mean & SD & Mean & $\mathrm{SD}$ & & & \\
\hline \multicolumn{8}{|c|}{ Mathematics } \\
\hline Happiness & 4.60 & .73 & 4.14 & .66 & .90 & $.41^{*}$ & 37.51 \\
\hline Pleasure & 4.15 & .66 & 4.03 & .67 & .99 & .09 & 1.55 \\
\hline Pride & 4.07 & .68 & 3.48 & .95 & .88 & .32 & 42.46 \\
\hline Encouragement & 4.60 & .69 & 4.00 & .73 & .84 & $.24^{*}$ & 61.18 \\
\hline Not angry-angry & 4.70 & .59 & 3.32 & 1.00 & .61 & .72 & 208.84 \\
\hline Cheerfulness & 4.09 & .48 & 3.38 & 1.00 & .87 & $.25^{*}$ & 47.94 \\
\hline Confidence & 4.68 & .68 & 4.00 & .710 & .83 & .41 & 67.17 \\
\hline Calmness & 4.00 & .80 & 3.40 & 1.09 & .93 & .23 & 22.49 \\
\hline Not anxiety-anxiety & 3.82 & .95 & 3.55 & .95 & .99 & .13 & 2.50 \\
\hline Enthusiasm & 4.60 & .94 & 4.50 & .69 & .99 & .01 & 1.34 \\
\hline \multicolumn{8}{|l|}{ Language } \\
\hline Happiness & 4.65 & .70 & 4.13 & .67 & .87 & .35 & 48.19 \\
\hline Pleasure & 4.07 & .66 & 4.10 & .67 & .99 & .02 & .17 \\
\hline Pride & 4.02 & .67 & 3.56 & .97 & .93 & .25 & 25.24 \\
\hline Encouragement & 4.76 & .58 & 3.91 & .70 & .70 & .60 & 140.27 \\
\hline Not anger-anger & 4.73 & .59 & 3.38 & 1.10 & .64 & .68 & 189.54 \\
\hline Cheerfulness & 4.13 & .47 & 3.48 & 1.02 & .86 & $.30^{*}$ & 51.26 \\
\hline Confidence & 4.70 & .60 & 4.07 & .76 & .83 & .41 & 68.98 \\
\hline Calmness & 4.00 & .80 & 3.53 & 1.05 & .94 & $.17 *$ & 19.36 \\
\hline Not anxiety-anxiety & 3.66 & .90 & 3.81 & 1.00 & .99 & .09 & 2.19 \\
\hline Enthusiasm & 4.62 & .94 & 4.53 & .71 & .99 & .04 & 1.66 \\
\hline
\end{tabular}

Note. $\mathrm{F}(1,340) \geq 19.36, \mathrm{p}<.01, \mathrm{~F}(1,340)<19.36, \mathrm{p}<.05 ; \mathrm{F}(1,340) \leq 2.50, \mathrm{p}>.05$; The nature of the emotions is positive and negative in the perceived successful and unsuccessful performance group, respectively; *: nonsignificant contribution in discriminating the two groups. 


\subsection{The Role of Hope in School Performance}

The results from the four Anovas, with the perceived (successful / unsuccessful) school performance as between subjects factor, and examination of the mean scores showed that the students who perceived their school performance as successful, in comparison to students who perceived their school performance as unsuccessful, had higher agency thinking and higher pathway thinking in both school subjects. The results from Discriminant function analyses (Table 3), with stepwise method, confirmed these findings, and, in addition, showed that agency thinking, as compared to pathway thinking, was a more powerful factor in discriminating the one from the other group of students in mathematics, discriminating power $=.95$, and in language, discriminating power $=.91$.

Table 3. Descriptive statistics and findings from discriminant analyses for the effects of students' hope (agency thinking, pathway thinking) on their perceived school performance in mathematics and language as successful or unsuccessful

\begin{tabular}{|c|c|c|c|c|c|c|c|}
\hline \multirow[b]{2}{*}{ Hope } & \multicolumn{2}{|l|}{$\begin{array}{l}\text { Successful } \\
\text { performance }\end{array}$} & \multicolumn{2}{|c|}{$\begin{array}{l}\text { Unsuccessful } \\
\text { performance }\end{array}$} & \multirow[b]{2}{*}{$\begin{array}{l}\text { Wilks' } \\
\text { Lambda }\end{array}$} & \multirow[b]{2}{*}{$\begin{array}{c}\text { Discriminating } \\
\text { power }\end{array}$} & \multirow[b]{2}{*}{$\mathrm{F}^{*}$} \\
\hline & Mean & SD & Mean & $\mathrm{SD}$ & & & \\
\hline \multicolumn{8}{|c|}{ Mathematics } \\
\hline Agency thinking & 16.35 & 2.36 & 12.80 & 2.60 & .66 & .95 & 173.64 \\
\hline Path thinking & 15.48 & 2.91 & 14.41 & 1.80 & .91 & .39 & 30.25 \\
\hline \multicolumn{8}{|c|}{ Language } \\
\hline Agency thinking & 16.15 & 2.47 & 12.65 & 2.40 & .87 & .91 & 165.48 \\
\hline Path thinking & 16.00 & 3.30 & 14.37 & 1.65 & .84 & .45 & 38.45 \\
\hline
\end{tabular}

Note. All F(1, 340)- values are significant at the .01 level of significance.

Because we were also interested in the role of hope within perceived (successful / unsuccessful) performance and school subject, correlations coefficients and regression analyses within each group of performance were conducted. The results from the analyses showed that higher levels of hope were related to less perceived unsuccessful performance, and more perceived successful performance in language and, particularly, in mathematics.

More precisely, in mathematics, in the perceived successful performance group, agency thoughts and pathways thoughts, together, influenced students' perceptions of performance, $\mathrm{R}^{2}=.10, \mathrm{~F}(2,176)=7.80, \mathrm{p}<.01$, agency thoughts, $\mathrm{b}=.28, \mathrm{t}=3.00, \mathrm{p}<.05$, had unique effect on it, while pathways thoughts had not significant effect, $\mathrm{b}$ $=.018, \mathrm{t}=1.05, \mathrm{p}>.05$. In the perceived unsuccessful performance group, pathways thoughts, $\mathrm{b}=.18, \mathrm{t}=2.80, \mathrm{p}$ $<.05$, and, mainly, agency thoughts, $\mathrm{b}=.78, \mathrm{t}=13.20, \mathrm{p}<.01$, influenced the generation of perceived performance positively, $\mathrm{R}^{2}=.45, \mathrm{~F}(2,160)=65.35, \mathrm{p}<.01$.

In language, in the successful performance group, agency thoughts and pathways thoughts, in combination, influenced students' perceptions of performance, $\mathrm{R}^{2}=.16, \mathrm{~F}(2,188)=7.80, \mathrm{p}<.01$, agency thoughts, $\mathrm{b}=.40, \mathrm{t}=$ $5.40, \mathrm{p}<.01$, had unique effect on it, while pathways thoughts had not significant effect, $\mathrm{b}=.016, \mathrm{t}=.95, \mathrm{p}>.05$. In the unsuccessful performance group, pathways thoughts, $\mathrm{b}=.15, \mathrm{t}=2.47, \mathrm{p}<.05$, and, mainly, agency thoughts, $\mathrm{b}=.37, \mathrm{t}=5.00, \mathrm{p}<.01$, influenced the generation of perceived performance positively, $\mathrm{R}^{2}=.29, \mathrm{~F}(2$, $148)=30.85, \mathrm{p}<.01$.

Thus, Hypotheses $3 \mathrm{a}$ and $3 \mathrm{~b}$ were partly confirmed.

\subsection{The Role of Hope on Attributions and Emotions for School Performance}

The results (Table 4) from a series of regression analysis, with agency thinking and pathway thinking as predictive variables and each of the attributional dimensions as predicted variable, within each group of perceived (successful / unsuccessful) performance and school subject (mathematics / language) revealed the significant role of hope.

More accurately, hope (mostly, agency thinking) influenced the formation of the attributional dimensions, mainly 
in the perceived unsuccessful performance group, and particularly in mathematics. Furthermore, agency thinking and pathway thinking, in combination, most influenced the formation of stability than of any other attributional dimension in the successful, $\mathrm{R}^{2}=.24, \mathrm{~F}(2,178)=28.50, \mathrm{p}<.01$, and unsuccessful, $\mathrm{R}^{2}=.31, \mathrm{~F}(2,166)=36.00, \mathrm{p}$ $<.01$, performance groups in mathematics, and in the successful performance group in language, $\mathrm{R}^{2}=.19, \mathrm{~F}(2$, $188)=22.85, \mathrm{p}<.01$. In the unsuccessful performance group in language, agency thinking and pathway thinking, as a group, was a best predictor of locus of causality, $\mathrm{R}^{2}=.29, \mathrm{~F}(2,148)=30.10, \mathrm{p}<.01$, than the other attributional dimensions.

In addition, in mathematics, higher-hope students, as compared with lower-hope students, made more internal (pathway thoughts had no effect), personal controllable, stable and external uncontrollable (pathway thoughts had no effect) attributions for their perceived successful performance, and more external (pathway thoughts had no effect), personal uncontrollable (agency thinking had no effect), unstable and external controllable attributions for their perceived unsuccessful performance.

In language, higher-agency hope students as compared with lower-agency hope students made more internal, stable and external uncontrollable attributions for their perceived successful performance, and more personal uncontrollable and unstable attributions for their perceived unsuccessful performance. High pathways- hope had positive impact only on personal controllable and external attributions for successful and unsuccessful performance, respectively.

Thus, Hypotheses $4 \mathrm{a}$ was in the main confirmed.

The results (Table 5) from a series of regression analysis, with agency thinking and pathway thinking as predictive variables and each of the emotions as predicted variable, within each group of perceived (successful / unsuccessful) performance and school subject (mathematics / language) showed that (a) hope positively influenced the formation of the emotions for the successful school performance and, mainly, unsuccessful school performance in language and in mathematics, (b) higher-hope students, as compared with lower-hope students, felt better for their performance in both school subjects, (c) hope was a more determinant factor in formulating the emotions of enthusiasm, encouragement and optimism than the rest of the emotions, (d) the relative power of pathway thinking and agency thinking in formulating emotional experience varied across emotions, school subjects and between the two groups of performance in each school subject, and (e) pathway thinking, in comparison to agency thinking, was a better predictor of most of the emotions in the successful and unsuccessful performance groups in both school subjects, while the pattern was reverse in angry and anxiety for unsuccessful performance in mathematics, in enthusiasm and cheerfulness for successful performance in mathematics, in sadness for unsuccessful performance in language, and in enthusiasm, pleasure and cheerfulness for successful performance in language.

The above findings confirmed the hypothesis $4 \mathrm{~b}$ partly.

Table 4. Findings from regression analyses for the effects of hope (agency thinking, pathway thinking) on the attributional dimensions for the perceived successful and unsuccessful school performance in mathematics and language

\begin{tabular}{|c|c|c|c|c|c|c|c|c|c|c|c|c|c|c|c|c|c|}
\hline \multirow{3}{*}{$\begin{array}{l}\text { Attributional } \\
\text { dimensions }\end{array}$} & & \multicolumn{8}{|c|}{ Mathematics } & \multicolumn{8}{|c|}{ Language } \\
\hline & & \multicolumn{3}{|c|}{ Successful performance } & & \multicolumn{4}{|c|}{ Unsuccessful performance } & \multicolumn{4}{|c|}{ Successful performance } & \multicolumn{4}{|c|}{ Unsuccessful performance } \\
\hline & ctors & $\mathrm{b}$ & $\mathrm{R}^{2}$ & $\mathrm{t}$ & $\mathrm{F}$ & $\mathrm{b}$ & $\mathrm{R}^{2}$ & $\mathrm{t}$ & $\mathrm{F}$ & $\mathrm{b}$ & $\mathrm{R}^{2}$ & $\mathrm{t}$ & $\mathrm{F}$ & $\mathrm{b}$ & $\mathrm{R}^{2}$ & $\mathrm{t}$ & $\mathrm{F}$ \\
\hline Locus of & A. $T h$ & .27 & & 3.65 & & .84 & & 7.44 & & .22 & & 2.73 & & .14 & & -- & 30.15 \\
\hline causality & P. Th & .043 & .063 & -- & 5.89 & .22 & .23 & -- & 24.57 & .045 & .042 & -- & 4.10 & .40 & .29 & 2.67 & \\
\hline Personal & A. $T h$ & .27 & & 3.30 & & .20 & & -- & & .094 & & -- & & .42 & & 2.75 & \\
\hline \multirow[t]{2}{*}{ controllability } & P. Th & .17 & 16 & 2.05 & 17.05 & .26 & .20 & 2.05 & 20.55 & .20 & .070 & 2.58 & 7.02 & .080 & .24 & -- & 24.50 \\
\hline & A. Th & .56 & & 7.06 & & .83 & & 6.70 & & .47 & & 6.40 & & .57 & & 3.48 & \\
\hline Stability & P. Th & .15 & .24 & 2.30 & 28.20 & .37 & .31 & 2.98 & 36.05 & .08 & .19 & -- & 22.96 & .20 & .15 & -- & 13.80 \\
\hline External & A. $T h$ & .22 & & 2.52 & & .58 & & 4.05 & & .23 & & 2.94 & & .32 & & -- & \\
\hline controllability & P. Th & .04 & .065 & -- & 38.19 & .49 & 093 & 3.42 & 8.22 & .005 & .055 & -- & 5.47 & .14 & .02 & -- & -- \\
\hline
\end{tabular}

Note. F $>4.40, \mathrm{p}<.01 ; \mathrm{F}<=4.40, \mathrm{p}<.05 ; \mathrm{F}--, \mathrm{p}>.05 ; \mathrm{t}>2.05, \mathrm{p}<.01 ; \mathrm{t}<2.05, \mathrm{p}<.05 ; \mathrm{t}--, \mathrm{p}>.05 ; \mathrm{A}$. Th $=$ Agency thinking, $\mathrm{P}$. Th $=$ Pathway thinking. 
Table 5. Findings from regression analyses for the effects of hope (agency thinking, pathway thinking) on the emotions for the perceived successful and unsuccessful school performance in mathematics and Language

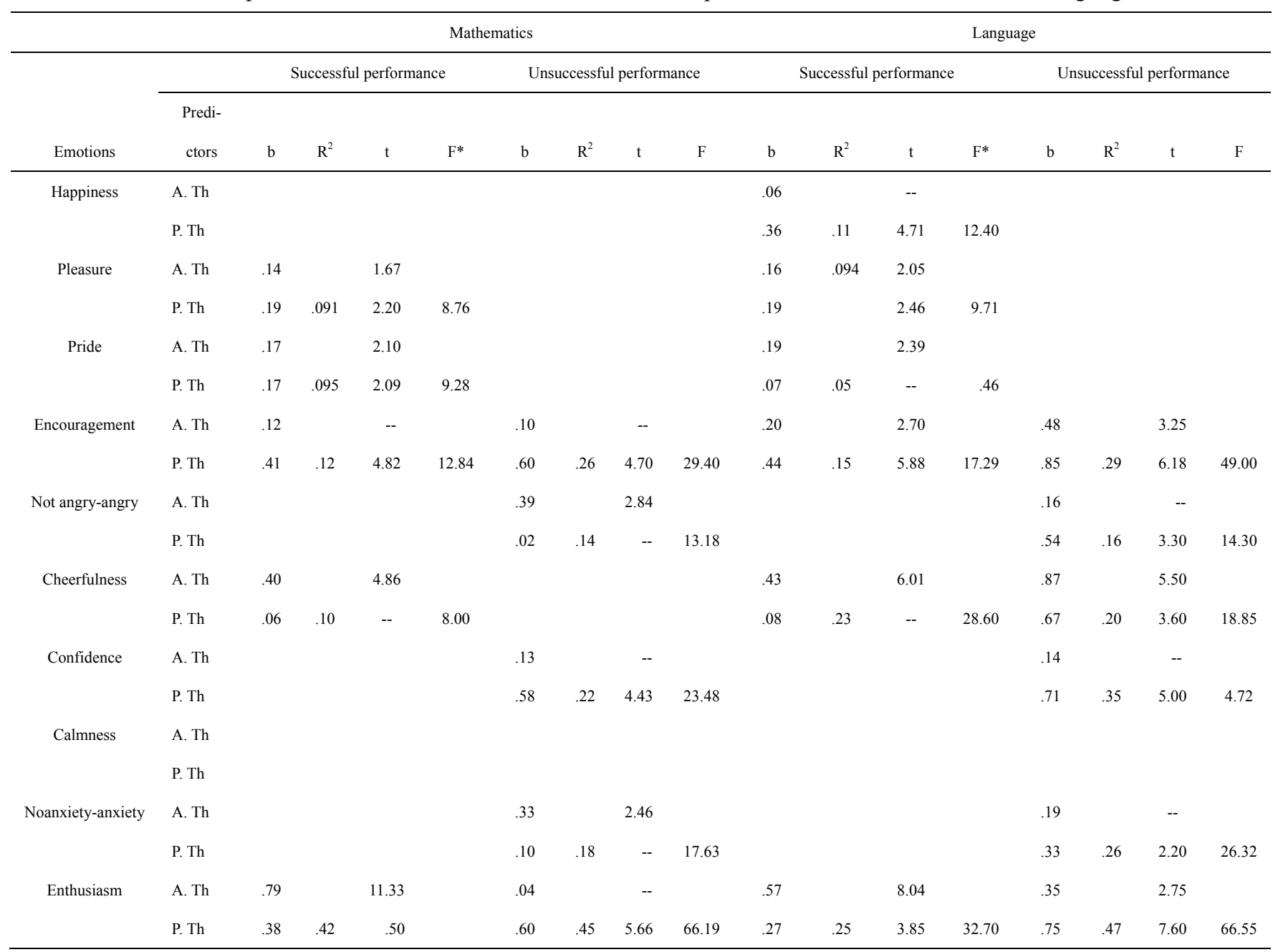

Note. *: All F- $\mathrm{p}<.01 ; \mathrm{t}>2.46, \mathrm{p}<.01 ; \mathrm{t}<2.46, \mathrm{p}<.05 ; \mathrm{t}--, \mathrm{p}>.05$; The nature of the emotions is positive and negative in the perceived successful and unsuccessful performance, respectively; $\mathrm{A}$. Th $=$ Agency thinking, $\mathrm{P} . \mathrm{Th}$ $=$ Pathway thinking.

\subsubsection{Effects of Hope on the Impact of Attributions on Emotions for School Performance}

Because we were also interested in the mediate role of hope in the impact of the attributions on the emotions for the perceived successful and unsuccessful school performance in language and in mathematics, a series of hierarchical regression analysis were conducted. Each of the emotions was the predicted variable, and attributional dimensions were entered at the first step, and agency thoughts and pathway thoughts were entered at the second step of the analysis.

The results from these analyses (Table 6) revealed that (a) hope and attributions, in combination, accounted for a significant variance in the emotions for the perceived successful school performance in mathematics, $\mathrm{R}^{2}$ range from .13 (pride) to .53 (enthusiasm), and in language, $\mathrm{R}^{2}$ range from .25 (happiness) to .49 (pleasure), and in the emotions for the perceived unsuccessful school performance in mathematics, $\mathrm{R}^{2}$ ranged from .35 (discouragement) to .56 (anxiety, non enthusiasm), and in language, $\mathrm{R}^{2}$ range from .41 (angry) to .75 (non enthusiasm), (b) hope (agency thinking and pathways thinking, together) enhanced the effects of attributions on some of the emotions in the successful performance groups in mathematic, $\mathrm{R}^{2} \mathrm{ch}$ ranged from .046 to .21 , and language, $\mathrm{R}^{2} \mathrm{ch}$ ranged from .056 to .12 , and in the unsuccessful performance groups in mathematics, $\mathrm{R}^{2} \mathrm{ch}$ ranged from .043 to .28 , and language, $\mathrm{R}^{2} \mathrm{ch}$ ranged from .06 to .23 . That means that the students with higher hope were more likely to use the specific attributional pattern and feel better for their school performance than the children with lower hope. Also, (c) both agency thinking and bath way thinking had unique effect on most of 
the emotions, with the exception being in the emotions of not anger - anger in both school subjects, pride for mathematics success (only for agency thinking) and pleasure for success in language (only pathway thinking). Finally, (d) locus of causality and personal controllability, as compared to the other attributional dimensions, were better predictors of most of the emotions for the unsuccessful math performance and the successful language performance, respectively.

Hypotheses $4 \mathrm{c}$ was partly confirmed.

Table 6. Results from hierarchical regression analyses for the impact of hope (agency thinking, path thinking) on the effects of attributions on emotions for the perceived successful / unsuccessful school performance in mathematics and language

\begin{tabular}{|c|c|c|c|c|c|c|c|c|}
\hline Emotions & Predictors & Steps & $\mathrm{R}^{2}$ & $\mathrm{R}^{2} \mathrm{ch}$ & Fch & $\mathrm{F}$ & beta & $\mathrm{t}$ \\
\hline & & & \multicolumn{6}{|c|}{ Successful performance in Mathematics } \\
\hline \multirow[t]{8}{*}{ Pride } & Attributions & 1 st & & & & & & \\
\hline & Locus of causality & & & & & & .03 & - \\
\hline & Personal controllability & & & & & & .16 & -- \\
\hline & Stability & & & & & & .10 & -- \\
\hline & External controllability & & .06 & & & 2.93 & .15 & 2.10 \\
\hline & Hope & 2nd & & & & & & \\
\hline & Agency thinking & & & & & & 11 & -- \\
\hline & Pathway thinking & & .13 & .07 & 6.97 & 4.41 & 12 & 2.35 \\
\hline \multirow[t]{8}{*}{ Encouragement } & Attributions & $1 \mathrm{st}$ & & & & & & \\
\hline & Locus of causality & & & & & & .32 & 3.92 \\
\hline & Personal controllability & & & & & & .40 & 5.80 \\
\hline & Stability & & & & & & .68 & 8.20 \\
\hline & External controllability & & .42 & & & 31.94 & .41 & 7.57 \\
\hline & Hope & 2nd & & & & & & \\
\hline & Agency thinking & & & & & & .44 & 6.41 \\
\hline & Pathway thinking & & .37 & .15 & 30.57 & 38.72 & .45 & 7.22 \\
\hline \multirow[t]{7}{*}{ Not angry } & Attributions & 1 st & & & & & & \\
\hline & Locus of causality & & & & & & .21 & 2.23 \\
\hline & Personal controllability & & & & & & .53 & 6.40 \\
\hline & Stability & & .34 & & & 30.45 & .32 & 3.28 \\
\hline & Hope & 2nd & & & & & & \\
\hline & Agency thinking & & & & & & .16 & -- \\
\hline & Pathway thinking & & .35 & .014 & -- & 19.23 & .11 & -- \\
\hline \multirow[t]{8}{*}{ Enthusiasm } & Attributions & 1 st & . & & & & & \\
\hline & Locus of causality & & & & & & .21 & 2.50 \\
\hline & Personal controllability & & & & & & .24 & 3.42 \\
\hline & Stability & & & & & & .18 & 2.15 \\
\hline & External controllability & & .32 & & & 20.45 & 19 & 3.40 \\
\hline & Hope & 2nd & & & & & & \\
\hline & Agency thinking & & & & & & .63 & 8.75 \\
\hline & Pathway thinking & & .53 & .21 & 40.15 & 33.15 & .41 & 6.30 \\
\hline
\end{tabular}


Unsuccessful performance in Mathematics

Attributions

Discouragement

Locus of causality

Personal controllability

Stability

Hope

Agency thinking

Pathway thinking

Non confidence

Attributions

Locus of causality

Personal controllability

Stability

Hope

Agency thinking

Pathway thinking

Anxiety

Non enthusiasm

Attributions

Locus of causality

Personal controllability

Stability

External controllability

Hope

Agency thinking

Pathway thinking

Attributions

Locus of causality

Personal controllability

Stability

External controllability

Hope

Agency thinking

Pathway thinking

$\begin{array}{ll}\text { Happiness } & \text { Attributions } \\ \text { Locus of causality } \\ \text { Stability } \\ \text { External controllability } \\ \text { Hope } \\ \text { Agency thinking } \\ \text { Pathway thinking } \\ \text { Attributions } \\ \text { Lleasure } & \text { Pecus of causality } \\ & \text { Stability } \\ \end{array}$

$1 \mathrm{st}$

\begin{tabular}{|c|c|c|c|c|c|}
\hline & & & .54 & 4.70 \\
\hline & & & & .18 & -- \\
\hline .35 & & & 29.43 & .22 & 2.55 \\
\hline & & & & .40 & 2.96 \\
\hline .45 & .096 & 13.83 & 26.05 & .59 & 4.91 \\
\hline
\end{tabular}

1 st

\begin{tabular}{|c|c|c|c|}
\hline & & .56 & 5.35 \\
\hline & & .28 & 3.70 \\
\hline .45 & 44.80 & .11 & -- \\
\hline
\end{tabular}

2nd

$\begin{array}{llllll}.53 & .085 & 14.56 & 36.78 & .57 & 4.59 \\ & & & & & \\ & & & & & \\ & & & \end{array}$

$1 \mathrm{st}$

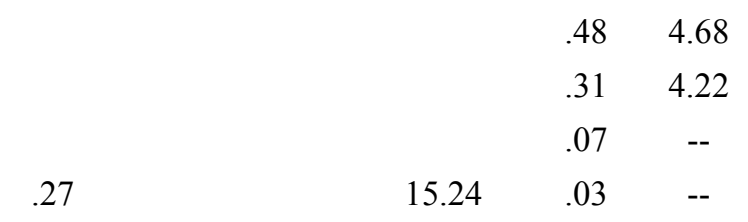

2nd

$\begin{array}{llllll}.56 & .28 & 50.97 & 33.58 & .37 & 3.85 \\ & & & & & \\ & & & & & \\ & & & \end{array}$

$1^{\text {st }}$

$.48 \quad 4.67$

$.32 \quad 4.39$

.08 --
.27
20.42

2nd

\begin{tabular}{|c|c|c|c|c|}
\hline & & & & .38 \\
\hline .56 & .28 & 51.06 & 40.40 & .85 \\
\hline
\end{tabular}

Successful performance in Language

$1 \mathrm{st}$

$$
\begin{aligned}
& .06 \\
& \begin{array}{llll}
.13 & 9.64 & .21 & 3.24
\end{array}
\end{aligned}
$$

2nd

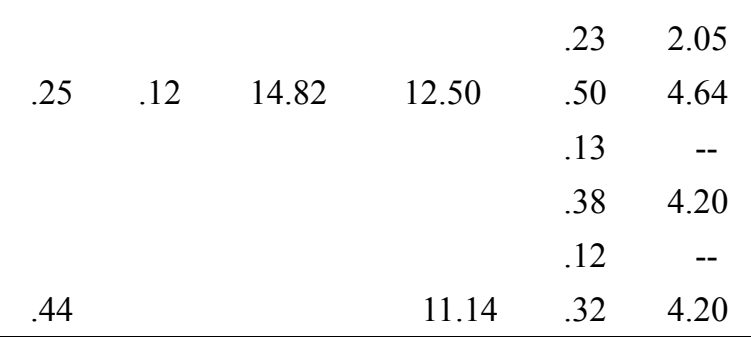


External controllability

Hope

Agency thinking

Pathway thinking

Not anger

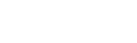

Enthusiasm

Unhappiness

Anger

Non confidence

Locus of causality

Personal controllability

Stability

External controllability

Hope

Agency thinking

Pathway thinking

Attributions

Personal controllability

Stability

External controllability

Hope

Agency thinking

Pathway thinking

Locus of causality

Personal controllability

Stability

External controllability

Hope

Agency thinking

Pathway thinking

Attributions

Locus of causality

Personal controllability

Stability

External controllability

Hope

Agency thinking

Pathway thinking

Attributions

Locus of causality

Personal controllability

Stability

External controllability

Hope

Agency thinking 2nd

$\begin{array}{rrrrrr} & & & & .17 & 2.95 \\ .49 & .051 & 6.17 & 9.95 & .11 & --\end{array}$

1 st

.26

2nd

$.28 \quad .021$

2.40

$1 \mathrm{st}$

2nd

$\begin{array}{lllll}.45 & .064 & 18.21 & 30.60 & .81\end{array}$

Unsuccessful performance in Language

1 st

2nd

1 st

2nd
.58

.40

.49

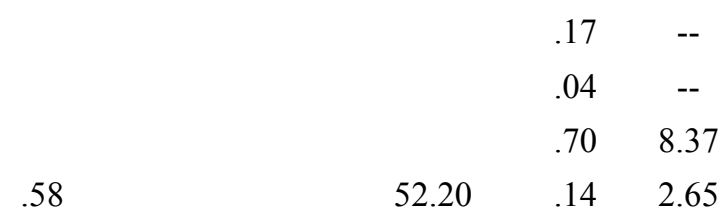

$\begin{array}{lll} & .59 & 5.16\end{array}$

$\begin{array}{llllll}.65 & .064 & 13.38 & 45.16 & .49 & 4.32\end{array}$

$1 \mathrm{st}$

\begin{tabular}{|c|c|c|c|}
\hline & & .55 & 4.69 \\
\hline & & .30 & 3.58 \\
\hline & & .24 & 2.60 \\
\hline .40 & 24.08 & .02 & -- \\
\hline
\end{tabular}

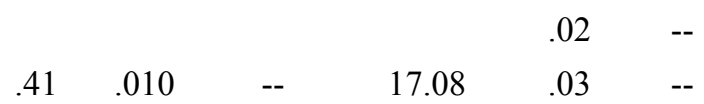

\begin{tabular}{|c|c|c|c|}
\hline & & .43 & 4.96 \\
\hline \multirow{4}{*}{.49} & & .41 & 6.46 \\
\hline & & .56 & 7.00 \\
\hline & 36.20 & .18 & 3.55 \\
\hline & & .51 & 4.67 \\
\hline
\end{tabular}




\begin{tabular}{|c|c|c|c|c|c|c|c|c|}
\hline & Pathway thinking & & .67 & .18 & 40.00 & 50.40 & .89 & 7.90 \\
\hline \multirow[t]{7}{*}{ Non enthusiasm } & Attributions & 1 st & & & & & & \\
\hline & Locus of causality & & & & & & .32 & 4.01 \\
\hline & Personal controllability & & & & & & .30 & 5.02 \\
\hline & Stability & & .46 & & & 42.05 & .33 & 4.45 \\
\hline & Hope & 2 nd & & & & & & \\
\hline & Agency thinking & & & & & & .46 & 4.30 \\
\hline & Pathway thinking & & .69 & .23 & 54.24 & 65.19 & .94 & 8.64 \\
\hline
\end{tabular}

Notes. Fch- values are significant at the .01 level of significance; $F=2.93, p<.05, F>2.93, p<.01 ; t>2.60, p$ $<.01, \mathrm{t} \leq 2.60, \mathrm{p}<.05 ;--: \mathrm{p}>.05$.

\subsection{Effects of Hope on Performance Expectations}

The results from a series of regression analysis, with agencythoughts and pathways thoughts as predictors and performance expectations as predicted variable, showed that in the perceived successful performance groups in both school subjects, high-pathway thinking children expected higher school performance. In contrast, in the perceived unsuccessful performance group in language, low-agency children had low expectations of future performance.

The findings regarding mathematics, in addition, showed that, in the perceived successful performance group, agency thoughts and pathways thoughts, together, influenced performance expectations, $\mathrm{R}^{2}=.35, \mathrm{~F}(2,176)=$ $48.00, \mathrm{p}<.01$, pathways thoughts, $\mathrm{b}=.64, \mathrm{t}=8.60, \mathrm{p}<.01$, had unique and positive effect on it, while agency thoughts had not significant effect, $\mathrm{b}=.08, \mathrm{t}=1.65, \mathrm{p}>.05$. Similarly, in the perceived unsuccessful performance group, pathways thoughts and agency thoughts, in combination, predicted performance expectations, $\mathrm{R}^{2}=.25$, $\mathrm{F}(2,160)=27.85, \mathrm{p}<.01$, pathways thoughts accounted in variance in it, $\mathrm{b}=.42, \mathrm{t}=3.50, \mathrm{p}<.01$, whereas agency thoughts, $\mathrm{b}=.10, \mathrm{t}=1.20, \mathrm{p}<.01$, had not significant effect.

The findings with respect to language, additionally, revealed that, in the perceived successful performance group, agencythoughts and pathways thoughts, together, influenced the generation of performance expectations, $\mathrm{R}^{2}$ $=.26, \mathrm{~F}(2,188)=34.40, \mathrm{p}<.01$, pathways thoughts, $\mathrm{b}=.53, \mathrm{t}=7.50, \mathrm{p}<.01$, had unique effect on it, while agency thoughts had not significant effect, $\mathrm{b}=.03, \mathrm{t}=.55, \mathrm{p}>.05$. In the perceived unsuccessful performance group, agency thoughts, $\mathrm{b}=.35, \mathrm{t}=2.95, \mathrm{p}<.05$, and, mainly, pathwaysthoughts, $\mathrm{b}=.57, \mathrm{t}=7.15, \mathrm{p}<.01$, influenced the formulation of performance expectations, $\mathrm{R}^{2}=.42, \mathrm{~F}(2,148)=52.100$.

Hypotheses 5 a was partly confirmed by the above findings.

\subsubsection{Effects of Hope on the Impact of Attributions and Emotions on Performance Expectations}

The main results from the four hierarchical regression analyses (Table 7), with performance expectations as predicted factor, and emotions for performance entering into first step, attributions for performance entering into second step and hope entering into third step of the analysis are the following: (a) the three sets of predictors, as a group, had significant and positive effect on the formation of performance expectations in the perceived successful, $\mathrm{R}^{2}=.80$, and unsuccessful, $\mathrm{R}^{2}=.72$, performance group in mathematics, and in the perceived successful, $\mathrm{R}^{2}=.74$, and unsuccessful, $\mathrm{R}^{2}=.87$, performance groups in language, (b) hope, attributions and emotions had unique and complimentarily effect on performance expectations, (c) pathway thoughts uniquely contributed into performance expectations, except in the perceived unsuccessful performance group in mathematics, whereas agency thinking explained a significant amount of the variability in performance expectations only in the perceived unsuccessful performance group in language, and (d) hope (pathways thinking and agency thinking, in combination) moderately influenced the interactive impact of attributions and emotions on performance expectations.

Hypotheses $5 \mathrm{~b}$ was partly confirmed by these findings. 
Table 7. Results from hierarchical regression analyses for the role of hope in the effect of attributions and emotions for the perceived successful/ unsuccessful performance on performance expectations in language and mathematics

\begin{tabular}{|c|c|c|c|c|c|c|c|}
\hline Predictors & Steps & $\mathrm{R}^{2}$ & $\mathrm{R}^{2} \mathrm{ch}$ & Fch & $\bar{F}$ & beta & $\mathrm{t}$ \\
\hline & \multicolumn{7}{|c|}{ Successful performance in Language } \\
\hline Emotions & $1 \mathrm{st}$ & & & & & & \\
\hline Pleasure & & & & & & .25 & 2.20 \\
\hline Pride & & & & & & .19 & 2.55 \\
\hline Cheerfulness & & & & & & .45 & 4.00 \\
\hline Confidence & & .62 & .62 & 29.76 & 29.76 & .18 & 3.60 \\
\hline Attributions & 2nd & & & & & & \\
\hline Stability & & .65 & .036 & 9.45 & 28.50 & .20 & 3.00 \\
\hline Hope & $3 \mathrm{rd}$ & & & & & & \\
\hline \multirow[t]{2}{*}{ Pathways thinking } & & .74 & .085 & 29.40 & 36.65 & .38 & 7.20 \\
\hline & \multicolumn{7}{|c|}{ Unsuccessful performance in Language } \\
\hline Emotions & $1 \mathrm{st}$ & & & & & & \\
\hline Unhappiness & & & & & & .20 & 2.40 \\
\hline Discouragement & & & & & & .31 & 6.20 \\
\hline Sadness & & & & & & .45 & 5.00 \\
\hline Not calmness & & & & & & .47 & 6.40 \\
\hline Anxiety & & & & & & .39 & 3.20 \\
\hline Not enthusiasm & & .71 & .71 & 57.00 & 57.00 & .46 & 5.40 \\
\hline Attributions & 2nd & & & & & & \\
\hline Locus of causality & & & & & & .59 & 3.80 \\
\hline Personal controllability & & & & & & .27 & 4.35 \\
\hline \multicolumn{8}{|l|}{ (Table 7 continue) } \\
\hline Stability & & .85 & .08 & 27.20 & 73.50 & .32 & 3.35 \\
\hline Hope & 3 rd & & & & & & \\
\hline Agency thinking & & & & & & .42 & 4.60 \\
\hline \multirow[t]{2}{*}{ Pathways thinking } & & .87 & .019 & 11.35 & 74.60 & .60 & 4.55 \\
\hline & \multicolumn{7}{|c|}{ Successful performance in Mathematics } \\
\hline Emotions & $1 \mathrm{st}$ & & & & & & \\
\hline Happiness & & & & & & .19 & 3.50 \\
\hline Pride & & & & & & .16 & 3.20 \\
\hline Encouragement & & & & & & .14 & 2.25 \\
\hline Not angry & & & & & & .19 & 2.35 \\
\hline Cheerfulness & & & & & & .38 & 4.25 \\
\hline Confidence & & .58 & .58 & 29.30 & 29.30 & .21 & 4.75 \\
\hline Attributions & $2 \mathrm{nd}$ & & & & & & \\
\hline Personal controllability & & & & & & .30 & 5.60 \\
\hline Stability & & .63 & .053 & 12.35 & 5.65 & .29 & 4.50 \\
\hline Hope & $3 \mathrm{rd}$ & & & & & & \\
\hline Pathways thinking & & .81 & .18 & 80.00 & 6.15 & .45 & 9.10 \\
\hline
\end{tabular}


Unsuccessful performance in Mathematics

\begin{tabular}{|c|c|c|c|c|c|c|c|}
\hline Emotions & 1 st & & & & & & \\
\hline Unhappiness & & & & & & .50 & 5.00 \\
\hline Not encouragement & & & & & & .56 & 5.40 \\
\hline Angry & & & & & & .17 & 2.55 \\
\hline Sadness & & & & & & .23 & 2.75 \\
\hline Anxiety & & .69 & .69 & 38.60 & 38.60 & .40 & 4.25 \\
\hline Attributions & 2nd & & & & & & \\
\hline Personal controllability & & & & & & .22 & 2.70 \\
\hline Stability & & .71 & .02 & 4.20 & 31.85 & .25 & 2.60 \\
\hline Hope & $3 \mathrm{rd}$ & & & & & & \\
\hline Pathways thinking & & .72 & .002 & -- & 27.25 & -- & \\
\hline
\end{tabular}

Notes. F- and Fch- values are significant at the .01 level of significance; $\mathrm{t} \leq 2.55, \mathrm{p}<.05, \mathrm{t}>2.55, \mathrm{p}<.01$, --: $\mathrm{p}>.05$.

\section{Discussion}

The main aim of this study was to investigate (a) possible differences between the students who perceivetheir school performance in language and mathematics either as successful or unsuccessful with respect to subsequent attributions and emotions, and to hope (pathways thinking, agency thinking), and (b) the role of hope in the generation of attributions, emotions and performance expectations, and in their inter- effects.

\subsection{Attributions and Emotions for School Performance}

The attributional pattern for the perceived successful and unsuccessful school performance in language and mathematics was in the main as expected.

Specifically, the children attributed their performance to various atrributional dimensions, reflecting the high importance of both school subjects for their personal identity, since under such conditions individuals search explanations (Weiner, 1992, 2005).

Also, by attributing the perceived successful school performance to internal, stable and personal controllable causes, the participants enhanced themselves and multiplied the probability of future success (see Mullen \& Riordan, 1988; Peterson \& Steen, 2005; Weiner, 1995, 2005). By attributing the perceived unsuccessful school performance to external and unstable (not in mathematics) factors, the children protected themselves and minimized the chances of future failure (Peterson et al., 1993; Stephanou, 2005, 2007b; Weiner, 2002). The high importance of the tasks for the participants and the desirable good performance contributed into these results. These findings may be also associated with the students' high motivation to succeed, and with the nature of the tasks (see Anderman \& Wolters, 2006; Pintrich \& Schunk, 2002). Language and Mathematics are major subjects of the school curriculum and successful school performance requires constant effort and aptitudes. Consequently, the perceived success was ascribed to adequate ability and high effort, whereas failure was not attributed to lack of these factors. The age of the participants may be another explanatory factor of these results. More precisely, the children, being at the specific age, might have expected positive performance, and confirmation or non confirmation of their expectations produced the specific attributional pattern (see Bless, 2003; Trope \& Gaunt, 2005). Further research is needed to examine the personal and psychological processes that seem to generate attributions in various school subjects during primary school.

However, it should be mentioned that attributing the perceived unsuccessful performance in mathematics to external uncontrollable and internal negative factors minimizes the chances for future success, and underestimates the teachers' beneficial role for the students (Schunk \& Zimmerman, 2006; Weiner, 1995, 2006). This later finding may be partly explained by the subjective or objective task difficulty and self-efficacy (Bandura, 1997; Wigfield \& Eccles, 1992). Perhaps, as previous studies have shown (e.g., De Corte, Op't Eynde, \& Verschaffel, 2002; Efklides, 2001; Stephanou, 2004a, 2004b, 2008), students doubted their abilities in this subject and considered mathematics as difficult. Besides, by 10 years of age, students begin to develop distinct views of their competence in different domains (Marsh, Craven \& Debus, 1998). However, this needs to be further investigated. 
The findings regarding the students' emotions for their school performance were in the main consistent with our hypotheses and previous research evidence. Perhaps, the high importance of good performance in mathematics and language for the children produced various emotions (Frijda, 1993, 2009; Goetz et al., 2003; Parrott, 2003), and contributed into discrimination the group of the children with the perceived unsuccessful performance from the group of the children with the perceived successful performance due to the attribution -dependent affects than the outcome- dependent affects. This specific finding is in the main against the Weiner's $(1992,2002,2005)$ theory but in line with the notion that students search for explanations of their performance in high ego involvement tasks (see Mullen \& Riordan, 1988; Peterson 1990).

Also, motivation in association with the age of the participants might have contributed to the observed intensity of the emotions in the perceived successful and unsuccessful school performance groups. Specifically, since the two school subjects were important for the students and they desired to succeed, they might have been motivated to see the task positively, and be optimistic about their performance. Thus, confirmation of high success expectations produced intense positive emotions (see Bless, 2003; Trope \& Gaunt, 2005), while the unexpected unsuccessful performance produced moderate negative emotions (see Carver \& Scheier, 2000; Frijda, 2007, 2009; Parrott, 2003). Furthermore, the elementary school children seemed to have been mastery goal orientation, which is related to positive emotions (Meece, Blumenfeld \& Hoyle, 1988; Smith, Sinclair, Chapman, 2002). Research needs to clarify such issues.

The two groups of the children in both school subjects were discriminated by the other- related emotions (angry-), followed by the expectancy- related affects (confidence, encouragement), and self- esteem related affects (pride). This specific finding is consistent with Weiner's (2001, 2002, 2005) model, research evidence and the notion that emotions are "socially constructed, personally enacted" (Lazarus, 1991; Schutz et al., 2006; Stephanou, 2007a, 2011b; Stephanou et al., 2011). However, the relative power of the emotions in discriminating the perceived successful from unsuccessful performance groups varied between the two school subjects. Similarly, the prevalence of the emotions varied within the perceived successful and unsuccessful performance groups.

It should be also mentioned that the experience of some certain negative motions does not facilitate future good school performance, especially in unsuccessful experience. For example, previous research evidence suggests that anger is positively related to attribute malicious intentions to others, and sadness shapes malicious attributions for low achievement (Pekrun, 2009; Schutz \& Lenehart, 2002). The students felt intense emotion of anxiety in mathematics in the successful and, mainly, in the unsuccessful performance group. Probably, as already mentioned, the students considered mathematics as difficult. This, latter finding is particular important because anxiety influence students to focus towards the self than to the content of the course and the strategies taking the course (Frijda, 2005).

Children also experienced discrete emotions by cognitively appraising their school performance along the attributional dimensions. More precisely, the attributional dimentions had unique effect on emotions, when hope entered into analysis, whose role is below discussed. The fact that attributions were more powerful contributor in the generation of the emotions in the perceived unsuccessful school performance groups than in the perceived successful school performance groups is consistent with the notion that individuals search for explanations of their negative than positive experiences (Weiner, 1992, 2002, 2005). The pattern of correlations between attributions and emotions partly supports that each attributional dimension is related to specific kind of emotions (Weiner, 2005, 2006). It seems that the students appraised the status of self- factors in pursuing their goals that include performing well in the specific activities in the classes and being good in the respective school subject, since such emotions are experienced in relationship to goals (Carver \& Scheier, 2000; Frijda, 2005, 2009; Linnenbrink \& Pintrich, 2002; Stephanou \& Kyridis, in press). However, this needs to be further investigated.

More precisely, locus of causality, as compared to the other attributional dimensions, was a better predictor of most of the emotions for the perceived unsuccessful performance in both school subjects. Personal controllability and stability, in comparison to the other attributional dimensions, proved the most powerful formulator of most of the emotions for the perceived successful performance in mathematics and the perceived language, respectively. Uunexpectedly, external controllable attributions played a significant role in students' emotions for performance in language, underling the children's sensitivity to significant others, such as teachers and classmates, in students' formation of emotional experience and motivation in particular academic tasks (Eccles \& Wigfield, 2000; Goetz et al, 2007; Hidi \& Harackiewicz, 2002; Stephanou, 2005, 2007b, 2011b; Weiner, 2002). Stability dimension partly confirmed Weiner's $(1992,2005)$ prediction that stable attributions influence the magnitude of self - related and, in particular, expectancy - related affects. 


\subsection{The Role of Hope in Attributions, Emotions, School Performance and Performance Expectation}

To summarize, the findings regarding hope were mainly consistent with our expectations. More precisely, in accordance to previous studies (see Roberts, 2005; Snyder et al., 2005), and Snyder's (2000) hope theory, the children with high hope achieved high performance, enjoyed their successful performance and used positive appraisal for their perceived successful performance in language and in mathematics. In a similar way, the high hope children, as compared to low hope children, performed better, suffered less and used effective appraisal for their perceived unsuccessful school performance in language and in mathematics. These findings indicate that the high hope children, not the low hope children, searched for something positive, a consistent finding with previous empirical evidence (see Carver \& Scheier, 2005). Hope was also a more powerful contributor into the generation of emotions and appraisals of the perceived unsuccessful school performance than the perceived successful school performance, complementarily to previous research evidence, which suggests that high hope people use positive reappraisal for a variety of stressor situation (see Gilham, 2000; Snyder et al., 1999).

On the other hand, the significant role of hope on the successful school performance experience is in line with Siegel (1992), who mentioned that "individual differences factors can influence both a child's responses to stress and his or her use of coping strategies" (p. 4). Further, as was indicated by Siegel and supported by respective research, children tend to respond to daily life stimuli by using the same mechanism of responding to stress (see for a review Roberts et al., 2005). Additionally, there is an increasing recognition that a comprehensive conceptualization of coping mechanisms views them as normal developmental components (Carr, 2005; Dryfoos, 1998; Jaycox, Reivich, Gilhan \& Seligman, 1994).

The differential contribution of pathway thinking and agency thinking to school performance, emotional experience, cognitive appraisals of school performance in language and mathematics is an indication that hope is interactively constructed by these two elements (see Snyder et al., 1991; Snyder et al., 2005). Contrarily to our hypothesis and previous literature, pathway thinking played a minor role in some of the emotions, in evaluating and in attributing causes of school performance. This may reflect the notion that agency thinking shares similarity with self-efficacy (Bandura, 1997), and, being the motivational component of hope, proved crucial in the case of difficulties, like unsuccessful performance (see Snyder, 1994; Stephanou, 2011b).

With reference to attributions, in addition, hope predominately influenced stability than the other attributional dimensions for the successful and unsuccessful performance in mathematics, and for the successful performance in language, while, unexpectedly, it mainly influenced locus of causality and personal controllability for the unsuccessful performance in language. These findings, probably, reflect the children's desire and assurance for successful school performance. These findings may also support other findings which reported that high-hope as compared with low-hope individuals tend to present themselves more positively and social desirable (Snyder, Hoza, et al., 1997; Taylor, 1989). In addition, hope proved a more powerful predictor of the attributional appraisal of school performance (particularly, unsuccessful) in mathematics than in language. This result is in line with high importance of mathematics in students' personal identity and academic development (Martin \& Debus, 1998; Mason, 2003; Stephanou, 2005, 2008). However, research needs to examine this speculation.

The pattern of the effects of hope on emotions is consistent with empirical evidence (see Roberts et al., 2005; Seligman, 2005) showing the important role of hope in expectancy (encouragement / discouragement, confidence / non confidence, enthusiasm / non enthusiasm)-, goal pursuit (pleasure/ displeasure, anxiety / non anxiety)-, self (pride)-, and other (non anger / anger)- related affects. Furthermore, hope had direct and indirect, through attributions, effect on the emotions for the perceived successful school performance, and, mainly, the perceived unsuccessful school performance.

The results from the present study also, confirming in the main our hypotheses, revealed that hope, attributions and emotions had unique and complimentarily effect on performance expectations. Specifically, the three sets of concepts, in combination, proved a more powerful predictor of performance expectations in the unsuccessful than successful performance in language, lending further support to the earlier findings (see Forgas \& Smith, 2005; Greitemeyer \& Weiner, 2003; Stephanou, 2007a, 2011a, 2011b; Weiner, 2005). However, unexpectedly, the three predictors, as a group, better predicted performance expectations in the successful than unsuccessful performance group in mathematics. Perhaps, as previous studies have shown (e.g., De Corte et al., 2002; Efklides, 2001; Stephanou, 2004a, 2004b, 2008), students doubted their abilities in this school subject and considered mathematics as difficult.

Also, in agreement with Weiner's $(1992,2005)$ model, the future (encouragement / discouragement, confidence / not confidence)- desirable high performance (pleasure / displeasure, cheerfulness)- goal (anxiety)- and other (not anger / anger)- related emotions contributed in performance expectations in both school subject. Stability, as 
expected, was a significant factor of the formation of performance expectation in all performance groups. However, unexpectedly, stability, compared to other attributional dimensions, had less effect in the generation of it in the unsuccessful performance group in language, reflecting, probably, children's beliefs that a such performance can become successful by controlling the situation. However, these need to be further investigated.

Similarly, in line with Snyder's (2000) theory and previous research evidence (e.g., Peterson, 2000; Scheier et al., 2000; Stephanou, 2011a), hope had direct and indirect (via the interaction of attributions and emotions) effect on performance expectations in all groups of children, expect unsuccessful performance in mathematics. That means that the children with higher pathway thinking were more likely to use the specific attributional pattern, enjoy their performance more and have higher expectations of good school performance than the children with lower pathway thinking. In contrast, in the unsuccessful group in language, the children with higher agency thinking and higher pathway thinking, as compared with the children with lower respective thinking, were more likely to apply the specific attributional pattern, suffer for failure to achieve their goal less, and expect future good school performance. Research needs to verify the relative role of pathway thinking and agency thinking in children's school performance across various school subjects.

\subsection{Implications of the Findings for Educational Practice and Future Research}

The present findings address the significant role of children's hope (pathways thinking, agency thinking) on the formation of their perceptions of school performance in language and mathematics as successful or unsuccessful, the subsequent attributions and emotions, and their performance expectations. Hence, children are needed to be helped maximize hopeful thinking. This is inculcated through interactions with their caretakers and teachers (McDermott \& Hastings, 2000; Snyder et al., 1997). Children should be encouraged to formulate clear goals, produce many and various pathways to these, pursue the goals and reframe obstacles as challenge to be overcome (Snyder, 2000).

The findings of this study, in addition, stress the high importance of students' cognitive and emotional involvement in school performance, and the significant effects of these processes on performance expectations. Attributional retraining (Seligman, 2002) helps children change maladaptive attributional pattern of school achievement. Also, students' recognition and regulation of their emotional experience is an essential part of successful learning and subjective well-being (Boekaerts et al., 2000; Efklides \& Volet, 2005; Frijda, 2005; Pekrun, 2009).

Conclusively the findings from this study stress the importance of examining children school performance along the role of hope in evaluating, attributing causes, experiencing emotions and forming expectations. Research is needed to examine the role of children's past experience, self-and task- beliefs on the observed associations, and on the consequences of the present emotional and cognitive pattern on academic development. Finally, research needs to investigate the role of parents' and teachers' support in children's hope thinking.

\section{References}

Ainley, M., Buckley, S., \& Chan, J. (2009). Interest and efficacy beliefs in self-regulated learning: Does the task make a difference? In M. Wosnitza, S. A. Karabenick, A. Efklides \& P. Nenniger (Eds.), Contemporary motivation research: From global to local perspectives. Cambridge: Hogrefe \& Huber.

Anderman, E. M., \& Wolters, C. A. (2006). Goals, values, and affcet: Influences on student motivation. In P. A. Alexander \& P. H. Winne (Eds), Handbook of Educational Psychology (pp. 369-389). London: Lawrence Erlbaum.

Anderman, L. H. (2004). Student motivation across subject-area domains. The Journal of Educational Research, 97(6), 283-285. http://dx.doi.org/10.3200/JOER.97.6.283-286

Bandura, A. (1997). Self-efficacy. New York: Freeman.

Barnum, D. D., Snyder, C. R., Rapof, M. A., Mani, M. M., \& Thompson, R. (1998). Hope and social support in the psychological adjustment of pediatric born survivors and matched controls. Children's Health Care, 27, 15 - 30. http://dx.doi.org/10.1207/s15326888chc2701_2

Berndsen, M., \& Manstead, A. S. R. (2007). On the relationship between responsibility and guilt: Antecedent appraisal or elaborated appraisal? European Journal of Social Psychology, 37, 774-792. http://dx.doi.org/10.1002/ejsp.397

Bless, H. (2003). The consequences of mood on the processing of social information.In A. Tesser \& N. Schwarz (Eds.), Handbook of Social Psychology: Intraindividual Processes (pp. 391- 412). Oxford: Blackwell.

Boakaerts, M. (2002). Toward a model that integrates motivation, affect, and learning. In L. Smith, C. Rogers, \& 
P. Tolminson (Eds.), Development and motivation: Joint perspectives (pp. 173-189). Leicester, England: British Psychological Society.

Boekaerts, M., Pintrich, P., \& Zeidner, M. (2000). Handbook of self-regulation. London: Academic.

Carr, A. (2005). Positive psychology. London: Routledge.

Carver, C. S., \& Scheier, M. F. (2005). Optimism. In C. R. Snyder, \& S. J. Lopez (Eds.), Handbook of Positive Psychology (pp. 231 -256). Oxford: University Press.

Chang, E. C. (1998). Hope, problem-solving ability, and coping in a college student population: Some implications for theory and practice. Journal of Clinical Psychology, 54, 953-962. http://dx.doi.org/10.1002/(SICI)1097-4679(199811)54:7<953::AID-JCLP9>3.0.CO;2-F

Cohen, J. (1992). A power primer. Psychological Bulletin, 112, 155-159. http://dx.doi.org/10.1037/0033-2909.112.1.155

Conti, R. (2000). College goals: Do self-determined and carefully considered goals predict intrinsic motivation, academic performance, and adjustement during the first semester? Social Psychology of Education, 4, 189-204. http://dx.doi.org/10.1023/A:1009607907509

Curry, L. A., Maniar, S. D., Sondag, K. A., \& Sandstedt, S. (1999). An optimal performance academic course for university students and student athletes. Unpublished manuscript. University of Montana, Missola.

De Corte, E., Op't Eynde, P., \& Verschaffel, L. (2002). Knowing what to believe: The relevance of students' mathematical beliefs for mathematics education. In B. K. Hofer \& P. R. Pintrich (Eds.), Personal epistemology: The psychology of beliefs about knowledge and knowing (pp. 297-320). Mahwah, NJ: Erlbaum.

Dermitzaki, I., \& Efklides, A. (2000). Self-concept and its relations with cognitive and metacognitive factors regarding performance in specific domains of knowledge [in Greek]. Psychology: The Journal of the Hellenic Psychological Society, 7, 354-368.

Diener, C. I., \& Dweck, C. S. (1980). An analysis of learned helplessness: The processing of success. Journal of Personality and Social Psychology, 30, 940 - 952. http://dx.doi.org/10.1037/0022-3514.39.5.940

Diener, E. (1984). Subjective well-being. Psychological Bulletin, 96, 542-575. http://dx.doi.org/10.1037/0033-2909.95.3.542

Dryfoos, J. G. (1998). Safe passages: Making it through adolescence in a risky society. Oxford: University Press.

Dweck, C. S. (1999). Self-theories: Their role in motivation, personality, and development. New York: Psychological Press.

Eccles, J. S., \& Wigfield, A. (1995). In the mind of the actor: The structure of adolescents' achievement task values and expectancy-related beliefs. Personality and Social Psychology Bulletin, 21, 215-225. http://dx.doi.org/10.1177/0146167295213003

Eccles, J. S., \& Wigfield, A. (2000). Schooling influences on motivation and achievement. In S. Danziuger \& J. Waldfogel (Eds.), Securing the future: Investing in children from birth to college (pp. 153-181). New York: Sage.

Eccles, J. S., \& Wigfield, A. (2002). Motivational beliefs, values and goals. Annual Review of Psychology, 53, 109-132. http://dx.doi.org/10.1146/annurev.psych.53.100901.135153

Efklides, A. (2001). Metacognitive experiences in problem solving: Metacognition, cognition and self regulation. In A. Efklides, J. Kuhl \& R. M. Sorrrentino (Eds.), Trends and prospects in motivation research (pp. 297-323). Dordrecht, The Netherands: Kluwer.

Efklides, A., \& Volet, S. (2005). Feelings and emotions in the learning process. Learning and Instruction, 15(5) [whole issue].

Ellsworth, P. C., \& Scherer, K. R. (2003). Appraisal processes in emotion. In R. J. Davidson, H. Goldsmith \& K. R. Scherer (Eds.), Handbook of the Affective Sciences (pp. 572-595). New York and Oxford: Oxford University Press.

Fiedler, K. (2000). Towards an integrative account of affect and cognition phenomena using the BIAS computer algorithm. In J. P. Forgas (Eds.), Feeling and thinking: affective influences on social cognition (pp. 223-252). Cambridge: Cambridge University Press. 
Fiske, S., \& Taylor, S. (1991). Social cognition. New York: McGraw-Hill.

Forgas, J. P., \& Smith, C. A. (2005). Affect and Emotion.In M. A. Hogg \& J. Cooper (Eds.), Handbook of social psychology (pp. 161 -189). London: Sage.

Frijda, N. H. (1988). The laws of emotion. American Psychologist, 43(5), 349-358. http://dx.doi.org/10.1037/0003-066X.43.5.349

Frijda, N. H. (1993). Appraisal and beyond: Special Issue of Cognition and Emotion. Hillsdale, N.J.: Erlbaum.

Frijda, N. H. (2005). Emotion experience. Cognition \& Emotion, 19, 473-498. http://dx.doi.org/10.1080/02699930441000346

Frijda, N. H. (2009). Emotions, individual differences, and time course: Reflections. Cognition and Emotion, 23, 1444-1461. http://dx.doi.org/10.1080/02699930903093276

Gasper, K. (2004). Permission to seek freely? The effect of happy and sad moods on generating old and new ideas. Creativity Research Journal, 16, 215-229.

Gilham, J. (2000). The science of optimism and hope. Philadelphia, PA: Templeton Foundation Press.

Goetz, T., Frenzel, A. C., Pekrun, R., Hall, N. C., \& Lüdtke, O. (2007). Between- and within-domain relations of students' academic emotions.Journal of Educational Psychology, 99, 715-733. http://dx.doi.org/10.1037/0022-0663.99.4.715

Goetz, T., Zirngibl, A., Pekrun, R., \& Hall, N. (2003). Emotions, learning and achievement from an educational-psychological perspective. In P. Mayring \& C. V. Rhoeneck (Eds.), Learning and emotions: The influence of affective factors on classroom learning (pp. 9-28). Frankfurt am Main: Peter Lang.

Graham, S., \& Hoehn, S. (1995). Children's understanding of aggression and withdrawal as social stigmas: An attributional analysis. Child Development, 66, 1143-1161. http://dx.doi.org/10.2307/1131804

Greitemeyer, T., \& Weiner, B. (2003). Asymmetrical attributions for approach versus avoidance behavior. Personality and Social Psychology Bulletin, 29, 1371-1382. http://dx.doi.org/10.1177/0146167203255766

Hannover, B., \& Kessels, U (2004). Self-to-prototype matching as a strategy for making academic choices. Why high school students do not like math and science. Learning and Instruction, 14(1), 51-67. http://dx.doi.org/10.1016/j.learninstruc.2003.10.002

Hanson, S. L. (1994). Lost talent: Unrilearlized educational aspirations and expectations among U.S. youths. Sociology of Education, 64, 263-277.

Harter, S. (1999). The construction of the self: A developmental perspective. New York: Guilford.

Hidi, S., \& Harackiewicz, J. M. (2002).Motivating the academically unmotivated: A critical issue for the 21 st century. Review of Educational Research, 70(2), 151-179.

Ilgen, D. R., \& Davis, C. A. (2000). Bearing bad news: Reactions to negative performance feedback. Applied Psychology: An International Review, 49, 550 - 565. http://dx.doi.org/10.1111/1464-0597.00031

Jaycox, L. I., Reivich, K. J., Gilhan, J., \& Seligman, M. E. P. (1994). Prevention of depressive symptoms in school children. Behavior Research and Therapy, 32, 801-816. http://dx.doi.org/10.1016/0005-7967(94)90160-0

Johnson, N. G., \& Roberts, M. C. (1999). Passage on the wild river of adolescence: arriving safely. In N. G. Johnson, M. C. Roberts \& J. Worell (Eds.), Beyond appearance: A new look at adolescent girls (pp. 3-18). Washinghton, DC: American Psychological Association.

Lazarus, R. S. (1991). Emotion and adaptation. New York: Oxford University Press.

Lewis, H. A., \& Kliewer, W. (1996). Hope, coping, and adjustment among children with sickle cell disease. Tests of mediator and moderator models. Journal of Pediatric Psychology, 21, 25-41. http://dx.doi.org/10.1093/jpepsy/21.1.25

Linnenbrink, E. A., \& Pintrich, P. R. (2002). Achievement goal theory and affect: An asymmetrical bidirectional model. Educational Psychologist, 37, 69-78. http://dx.doi.org/10.1207/S15326985EP3702_2

Linnenbrink, E., A., \& Pintrich, P. R. (2000). Multiple pathways to learning and achievement: The role of goal orientation in fostering adaptive motivation, affect and cognition. In C. Sansone \& M. J. Harackiewicz (Eds.), Intrinsic and extrinsic motivation: The search for optimal motivation and performance (pp. 195 - 227). San Diego, CA: Academic press. 
Lopez, S. J., Bouwkamp, J., Edwards, I. M., \& Teramoto Pediotti, J. (2000). Making hope happens via brief interventions. Paper presented at the Second Positive Psychology Summit, Washington, DC.

Marsh, H. W., \& Craven, R. G. (1997). Academic self -concept: Beyond the dustbowl. In G. Phye (Eds.), Handbook of classroom assessment: Learning, achievement and adjustment (pp. 131- 198). U. S: Academic Press.

Marsh, H. W., Craven, R. G., \& Debus, R. (1998). Structure, stability, and development of young children's self concepts: A multicohort-multioccasion study. Child Development, 69(4), 1030-1053.

Mason, L. (2003). High school students' beliefs about math, mathematical problem -solving, and their achievement in math: a cross-sectional study. Educational Psychology, 23, 73-85. http://dx.doi.org/10.1080/01443410303216

McAuley, E., Duncan, T. E., \& Russell, D. W. (1992). Measuring causal attributions: The revised Causal Dimension Scale (CDSII). Personality and Social Psychology Bulletin, 18, 566 - 573. http://dx.doi.org/10.1177/0146167292185006

McDermott, D., \& Hastings, S. (2000). Children: Raising future hopes. In C. R. Snyder (Eds.), Handbook of hope: Theory, measures, and applications (pp. 185 -199). San Diego, CA: Academic Press.

McDermott, D., \& Snyder, C. R. (2000). The great big book of hope. Oakland, CA: New Harbinger Publications.

Meece, J. L., Blumenfeld, P. B., \& Hoyle, R. H. (1988). Students' goal orientation and cognitive engagement in

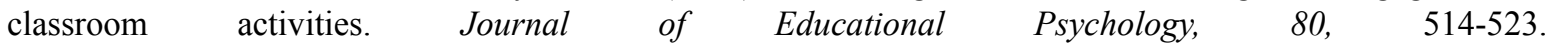
http://dx.doi.org/10.1037/0022-0663.80.4.514

Meyer, D. K., \& Turner, J. C. (2002). Discovering emotion in classroom motivation research. Educational Psychologist, 37(2), 107 - 114. http://dx.doi.org/10.1207/S15326985EP3702_5

Mullen, R., \& Riordan, C. A. (1988). Self-serving attributions for performance in naturalistic settings: A meta-analytic review. Journal of Applied Social Psychology, 18, 3-22. http://dx.doi.org/10.1111/j.1559-1816.1988.tb00001.x

Nagy, G., Trautwein, U., Baumert, J., Koller, O., \& Garrett, J. (2006). Gender and course selection in upper secondary education: Effects of academic self-concept and intrinsic value. Educational Research and Evaluation, 21(4), 323-345. http://dx.doi.org/10.1080/13803610600765687

Nolen-Hoeksema, S., \& Davis, C. G. (2005). Positive responses to loss: Perceiving benefits and growth. In C. R. Snyder \& S. J. Lopez (Eds.), Handbook of Positive Psychology (pp. 598 - 607). Oxford: University Press.

Ortony, A., Clore, G. L., \& Collins, A. (1988). The cognitive structure of emotions. Cambridge: University Press. http://dx.doi.org/10.1017/CBO9780511571299

Paris, S. G., Morrison, F. J., \& Miller, K. F. (2006).Academic pathways from preschool throught elementary school.In P. A. Alexander \& P. H. Winne (Eds.), Handbook of Educational Psychology (pp. 61 - 85). London: Lawrence Erlbaum.

Parrott, W. G. (2003). The nature of emotions. In A. Tesser \& N. Schwarz (Eds.), Handbook of Social Psychology: Intraindividual processes (pp. 375- 390). Oxford: Blackwell.

Pekrun, R. (2005). Progress and open problems in educational emotion research. Learning and Instruction, 15, 497-506. http://dx.doi.org/10.1016/j.learninstruc.2005.07.014

Pekrun, R. (2009). Emotions at school. In K. R. Wentzel \& A. Wigfield (Eds.), Handbook of motivation in school (pp. 575-605). New York: Routledge Taylor.

Pekrun, R., \& Schutz, P. A. (2007). Where do we go from here? Implications and future directions for inquiry on emotions in education. In P. A. Schutz \& R. Pekrun (Eds.), Emotion in education (pp. 313-331). San Diego, CA: Academic Press.

Pekrun, R., Goetz, T., Daniels, L. M., Stupnisky, R. H., \& Perry, R. P. (2010). Boredom in achievement settings: Control-value antecedents and performance outcomes of a neglected emotion. Journal of Educational Psychology, 102, 531-549. http://dx.doi.org/10.1037/a0019243

Peterson C., \& Steen, T. A. (2005). Optimistic explanatory style. In C. R. Snyder \& S. J. Lopez (Eds.), Handbook of Positive Psychology (pp. 244 -256). Oxford: University Press.

Peterson, C. (2000). The future of optimism. American Psychologist, 55, 44-55. http://dx.doi.org/10.1037/0003-066X.55.1.44 
Peterson, C., Maier, S., \& Seligman, M. (1993). Learned helplessness: A theory for the age of personal control. New York: Oxford University press.

Peterson, S. J., Gerhardt, M. W., \& Rode, J. C. (2006). Hope, learning goals, and task performance. Personality and Individual Differences, 40, 1099-1109. http://dx.doi.org/10.1016/j.paid.2005.11.005

Pintrich, P. R. (2003). A motivational science perspective on the role of student motivation in learning and teaching contexts. Journal of Educational Psychology, 95(4), 667-686. http://dx.doi.org/10.1037/0022-0663.95.4.667

Pintrich, P. R., \& Schunk, D. (2002). Motivation in education: Theory, research, and applications (2nd ed.). Upper Saddle River, NJ: Prentice Hall.

Roberts, M. C., Brown, K. J., Johnson, R. J., \& Reinke, J. (2005). Positive psychology for children: Development, prevention, and promotion. In C. R. Snyder \& S. J. Lopez (Eds.), Handbook of Positive Psychology (pp. 663 - 686). Oxford: University Press.

Ruehlman, L. S., \& Wolchik, S. A. (1988). Personal goals and interpersonal support and hindrance as factors in psychological distress and well-being. Journal of Personality and Social Psychology, 55, 293-301. http://dx.doi.org/10.1037/0022-3514.55.2.293

Rutter, M., \& Maughan, B. (2002).School effectiveness findings 1979-2002. Journal of School Psychology, 40(6), 451-475. http://dx.doi.org/10.1016/S0022-4405(02)00124-3

Scheier, M. F., \& Carven, C. S. (1985). Optimism, coping, and health: Assessment and implications of $\begin{array}{llll}\text { generalized outcome } & \text { expectations. Health } & \text { Psychology, } & 4 \text {, } 247 .\end{array}$ http://dx.doi.org/10.1037/0278-6133.4.3.219

Scheier, M. F., Carver, C., \& Bridges, M. (2000). Optimism, pessimism and psychological well-being. In E. Chang (Eds.), Optimism and Pessimism: Theory, Research and Practice. Washington, DC: American Psychological Association.

Schunk, D. H., \& Zimmerman, B. J. (2006). Distinguishing the means and ends. In P. A. Alexander \& P. H. Winne (Eds.), Handbook of Educational Psychology (pp. 349 - 368). London: Lawrence Erlbaum.

Schutz, P. A., Hong, J. Y., Cross, D. I., \& Osbon, J. N. (2006). Reflectionson investigating emotions among $\begin{array}{lllll}\text { educational contexts. Educational Psychology Review, } & 18, \quad 343-360 .\end{array}$ http://dx.doi.org/10.1007/s10648-006-9030-3

Schutz, P. A., \& DeCuir, J. T. (2002). Inquiry on emotions in education. Educational Psychologist, 37(2), 125 134. http://dx.doi.org/10.1207/S15326985EP3702_7

Schutz, P. A., \& Lenehart, S. J. (2002). Emotions in education. Educational Psychologist, 37(2), 67-78. http://dx.doi.org/10.1207/S15326985EP3702_1

Seligman, M. E. P. (1991). Learned optimism. New York: Knopf.

Seligman, M. E. P. (2002). Authentic happiness: Using the new positive psychology to realise your potential for lasting fulfilment. New York: Free Press.

Seligman, M. E. P. (2005). Positive psychology, Positive prevention, and Positive therapy. In In C. R. Snyder, \& S. J. Lopez (Eds.), Handbook of Positive Psychology (pp. 3-9). Oxford: University Press.

Siegel, L. J. (1992). Overview. In A. M. La Greca, L. J. Siegel, J. L. Wallander \& C. E. Walker (Eds.), Stress and coping in child health (pp. 3-6). New York: Guilford.

Smith, C. A., \& Ellsworth, P. C. (1987). Patterns of appraisal and emotion related to taking an exam. Journal of Personality and Social Psychology, 52, 475 - 488. http://dx.doi.org/10.1037/0022-3514.52.3.475

Smith, C. A., \& Kirby, L. D. (2000). Consequences require antecedents: Toward a process model of emotion elicitation. In J. Forgas (Eds.), Feeling and Thinking: The role of affect in social cognition (pp. 83-106). New York: Cambridge University Press.

Smith, C. A., \& Lazarus, R. S. (1990).Emotions and adaptation. In L. A. Pervin (Ed.), Handbook of personality: Theory and research (pp. 609-637). New York: Guilford.

Smith, L., Sinclair, K. E., \& Chapman, E. S. (2002). Students' goals, self-efficacy, self-handicapping, and negative affective responses: An Australian senior school study. Contemporary Educational Psychology, 27, 471-485. http://dx.doi.org/10.1006/ceps.2001.1105 
Snyder, C. R. (2000). Handbook of hope. Orlando FL: Academic press.

Snyder, C. R., Cheavens, J., \& Michael, S. T. (1999). Hoping. In C. R. Snyder (Eds.), Coping: The psychology of what works (pp. 205 - 231). New York: Oxford University Press.

Snyder, C. R., Cheavens, J., \& Sympson, S. C. (1997). Hope: An individual motive for social commerce. Group Dynamics: Theory, Research and Practice, 1, 107-118. http://dx.doi.org/10.1037/1089-2699.1.2.107

Snyder, C. R., Feldman, D. B., Taylor, J. D., Schroeder, L. L., \& Adams, V. (2000). The roles of hopeful thinking in preventing problems and enhancing strengths. Applied and Preventive Psychology, 15, 262-295.

Snyder, C. R., Harris, C., Anderson, J. R., Holleran, S. A., Irving, L. M., Sigmon, S.T., Yoshinobu, L., Gibb, J., Langelle, C., \& Harney, P. (1991). The will and the ways: Development and validation of an individual differences measure of hope. Journal of Personality and Social Psychology, 60, 570-583. http://dx.doi.org/10.1037/0022-3514.60.4.570

Snyder, C. R., Hoza, B., Pelham, W. E., Rapoff, M., Ware, L., Danovsky, M., Highberger, L., Rubinstein, H., \& Stahl, K. J. (1997).The development and validation of the Children's Hope Scale. Journal of Pediatric Psychology, 22, 399-421. http://dx.doi.org/10.1093/jpepsy/22.3.399

Snyder, C. R., Irving, L., \& Anderson, J. R. (1991). Hope and health: Measuring the will and the ways. In C. R. Snyder \& D. R. Forsyth (Eds.), Handbook of Social and clinical psychology: The health perspective (pp. 285 - 305). Elmsford, NY: Pergamon.

Snyder, C. R., McDermott, D., Cook, W., \& Rapoff, M. (1997). Hope for the journey: Helping children through the good time and the bad. San Francisco: HarperCollins.

Snyder, C. R., Rand, K. L. R., \& Sigmon, D. R. (2005). Hope theory. In C. R. Snyder, \& S. J. Lopez (Eds.), Handbook of Positive Psychology (pp. 257 -276). Oxford: University Press.

Snyder, C. R., Shorey, H. S., Cheavens, J., Pulvers, K. M., Adams III, V. H., \& Wiklund, C. (2002). Hope and academic success in college.Journal of Educational Psychology, 94(4), 820-826. http://dx.doi.org/10.1037/0022-0663.94.4.820

Snyder, C. R., Sympson, S. C., Ybasco, F. C., Borders, T. E., Babyak, M. A., \& Higgins, R. L. (1996). Development and validation of the State Hope Scale. Journal of Personality and Social Psychology, 70, 321-335. http://dx.doi.org/10.1037/0022-3514.70.2.321

Snyder. (1994). Hope and optimism.In V. S. Ramachandren (Eds.), Encyclopedia of human behaviour (Vol. 2, pp. 535-542). San Diego, CA: Academic Press.

Stephanou, G., \& Tatsis, K. (2008). Effects of Value Beliefs, Academic self-esteem, and Overgeneralization of Failure Experience on the Generation of Emotions and Attributions for Academic Performance. International Journal of Learning, 15(11), 201- 220.

Stephanou, G. (2004a). Ability self-perception, perceived task difficulty, performance expectations, and task value in language and mathematics: Their relationship to academic performance and educational choice [in Greek]. In M. Dikaiou, P. Roussi \& D. Cristidis (Eds.), Scientific Annals of the School of Psychology (Vol. VI, pp. 65-93). Thessaloniki, Greece: Aristotle University of Thessaloniki / ArtofText.

Stephanou, G. (2004b). Effects of ability self-perception, perceived task-difficulty, performance expectations and importance of performance on performance and attributions in specific academic domains. In J. Baumert, $\mathrm{H}$. W. Marsh, U. Trautwein \& G. E. Richards (Eds.), Proceedings of the 3rd International SELF Research Conference: Self-Concept, Motivation and Identity (CD form). Berlin, Germany: Max Planck Institute for Human Development.

Stephanou, G. (2005). Academic performance and interpersonal relationships [in Greek]. In F. Vlachos, F. Bonoti, P. Metallidou, I. Dermitzaki \& A. Efklides (Eds.), Human behavior and learning. Scientific Annals of the Psychological Society of Northern Greece (Vol. 3, pp. 201-228). Athens: Ellinika Grammata.

Stephanou, G. (2006). Effects of cognitive factors and teacher effectiveness on students' academic emotions and performance. In R. G. Graven, J. Eccles \& M. Tr. Ha (Eds.), Proceedings of the 4rd International SELF Research Conference: Self-Concept, Motivation, Social and Personal Identity for the 21tst Century (CD form). Sydney, Australia: SELF Research Center, University of Western Sydney. http//self.uws.edu.au.

Stephanou, G. (2007a). Effects of cognitive and perceived teacher- related factors on student emotions in physical education. In Y. Theodorakis, M. Goudas \& A. Papaioannou (Eds.), Proceedings of the $12^{\text {th }}$ European Congress of Sport Psychology, Sport and Exercise Psychology.Bridges between disciplines and culture, 242 - 
247.Halkidiki - Greece: University of Thessaly \& European Federation of Sport Psychology.

Stephanou, G. (2007b). Students' appraisals and emotions for interpersonal relationships with teachers. In S. Vosniadou, D. Kayser \& A. Protopapas, Proceedings of The European Cognitive Science Conference (pp. 568-574). Canada: Lawrence Erlibaum Associates.

Stephanou, G. (2008). Students' value beliefs, performance expectations, and school performance: The effect of school subject and gender. Hellenic Journal of Psychology: The Journal of the Psychological Society of Northern Greece, 5, 231-257.

Stephanou, G. (2011a). Children friendship: the role of hope in attributions, emotions and expectations. Psychology, 2(8), 875-888. http://dx.doi.org/10.4236/psych.2011.28133

Stephanou, G. (2011b). Students' classroom emotions: Cognitive antecedents and school performance. Electronic Journal of Research in Educational Psychology, 9 (1), 5-48.

Stephanou, G., \& Balkamou, K. (in press). Children's attributions and emotions for their friendships with their best friend. Psychology Research.

Stephanou, G., Kariotoglou, P., \& Ntinas, K. (2011). University students' emotions in lectures: The effect of competence beliefs, value beliefs and perceived task-difficulty, and the impact on academic performance. International Journal of Learning, 18(1), 45-72.

Stephanou, G., \& Kyridis, A. (in press). University Students' Perceptions of Teacher Effectiveness and Emotions in Lectures: The Role of Socio-cognitive Factors, and Academic Performance. International Education Studies, $5(2)$.

Taylor, S. E. (1989). Positive illusions: Creative self-deception and the healthy mind. New York: Basic Books.

Trope, Y., \& Gaunt, R. (2005).Attribution and person perception. In M. A. Hogg \& J. Cooper (Eds.), Handbook of social psychology (pp. 190 - 208). London: Sage.

Weiner, B. (1992). Human motivation: Metaphors, theories and research. London: Sage.

Weiner, B. (1995). Judgments of responsibility: A foundation for a theory of social conduct. New York: Guilford.

Weiner, B. (2001). Intrapersonal and interpersonal theories of motivation from an attributional perspective. Educational Psychology Review, 12, 1-14. http://dx.doi.org/10.1023/A:1009017532121

Weiner, B. (2002). Social emotions and personality inferences: A Scaffold for a new direction in the study of achievement motivation. Key Speech atthe 8th WATM \& Motivation and Emotion Conference, Moskow, Russia.

Weiner, B. (2005). Motivation from an attribution perspective and the social psychology of perceived competence. In Elliot, A. J., \& Dweck, C. S. (Eds.), Handbook of Competence and Motivation (pp. 73-84). New York: Guilford.

Weiner, B. (2006). Social motivation, justice, and the moral emotions: An attributional approach. Mahwah, N.J: Erlbaum.

Weinstein, C. (1998). Promoting positive expectations in schooling. In N. Lambert \& B. M. Lombs (Eds.), How students learn: Performing schools through learner-centered education (pp. 81-111). Washington, DC: American Psychological Association. http://dx.doi.org/10.1037/10258-003

Wigfield, A., \& Eccles, J. (2002). The development of competence beliefs and values from childhood through adolescence. In A. Wigfield \& J. S. Eccles (Eds.), Development of achievement motivation (pp. 92-120). San Diego, CA: Academic. http://dx.doi.org/10.1016/B978-012750053-9/50006-1

Wigfield, A., Brynes, J. P., \& Eccles, J. S. (2006). Development during early and middle adolescence. In P. A. Alexander \& P. H. Winne (Eds.0), Handbook of Educational Psychology (pp. 87-113). London: Lawrence Erlbaum.

Wigfield, A., Guthrie, J., Tonks, S., \& Perencevich, K. (2004). Children's motivation for reading: Domain specificity and instructional influences. The Journal of Educational Research, 97, 299-309. http://dx.doi.org/10.3200/JOER.97.6.299-310

Wolters, A., \& Pintrich, P. R. (1998). Contextual differences in student motivation and self-regulated learning in mathematics, English, and social studies classrooms. Instructional Science, 26, 27-47. http://dx.doi.org/10.1023/A:1003035929216 
Wosnitza, M., Karabenick, S. A., Efklides, A., \& Nenniger, P. (2009). Introduction. In M. Wosnitza, S. A. Karabenick, A. Efklides \& P. Nenniger (Eds.), Contemporary motivation research: From global to local perspectives (pp. vii-xi). Cambridge: Hogrefe \& Huber Publishers.

Zimmerman, B. I. (2000). Self-efficacy: an essential motive to learn. Contemporary Educational Psychology, 25, 82-91. http://dx.doi.org/10.1006/ceps.1999.1016

Zimmerman, B. J. (1995). Self-efficacy and educational development. In A. Bandura (Ed.), Self-efficacy in changing societies (pp. 202-231). NewYork: Cambridge University Press. 